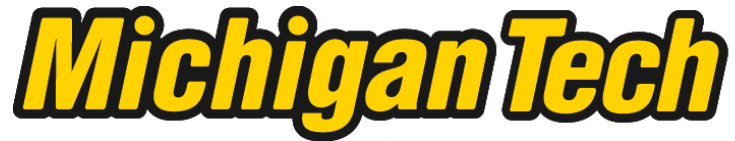 \\ Michigan Technological University Create the Future Digital Commons @ Michigan Tech
}

2015

\section{A CASE STUDY OF DATA IN THE MANAGEMENT OF WATER RESOURCES IN THE GUNNISON RIVER BASIN, COLORADO}

Rhianna L. Williams

Michigan Technological University

Follow this and additional works at: https://digitalcommons.mtu.edu/etds

Part of the Environmental Sciences Commons, Organizational Behavior and Theory Commons, and the Social and Behavioral Sciences Commons

Copyright 2015 Rhianna L. Williams

\section{Recommended Citation}

Williams, Rhianna L., "A CASE STUDY OF DATA IN THE MANAGEMENT OF WATER RESOURCES IN THE GUNNISON RIVER BASIN, COLORADO", Master's Thesis, Michigan Technological University, 2015.

https://doi.org/10.37099/mtu.dc.etds/972

Follow this and additional works at: https://digitalcommons.mtu.edu/etds

Part of the Environmental Sciences Commons, Organizational Behavior and Theory Commons, and the Social and Behavioral Sciences Commons 


\title{
A CASE STUDY OF DATA IN THE MANAGEMENT OF WATER RESOURCES IN THE GUNNISON RIVER BASIN, COLORADO
}

By

Rhianna L. Williams

\begin{abstract}
A THESIS
Submitted in partial fulfillment of the requirements for the degree of MASTER OF SCIENCE

In Environmental and Energy Policy
\end{abstract}

\section{MICHIGAN TECHNOLOGICAL UNIVERSITY}

2015

(C) 2015 Rhianna L. Williams 
This thesis has been approved in partial fulfillment of the requirements for the Degree of MASTER OF SCIENCE in Environmental and Energy Policy.

\title{
Department of Social Sciences
}

\author{
Thesis Advisor: $\quad$ Richelle Winkler \\ Committee Member: Carol MacLennan \\ Committee Member: Blair Orr \\ Department Chair: PatMartin
}




\section{Table of Contents}

Table of Contents ............................................................................................. 3

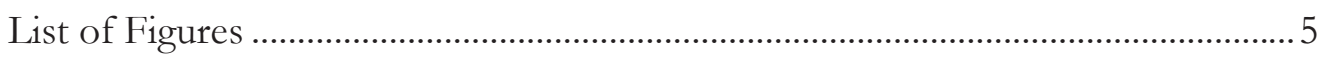

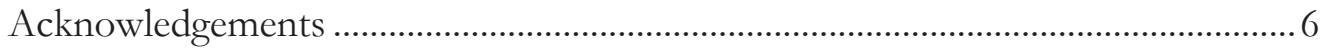

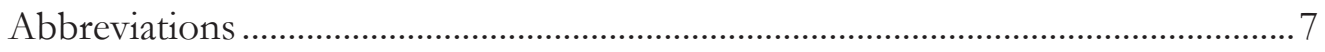

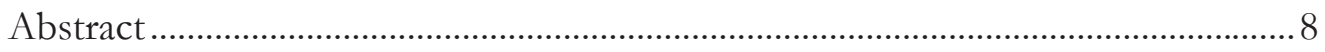

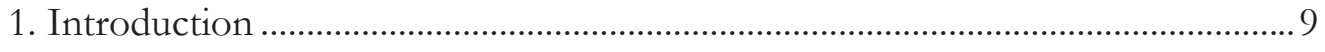

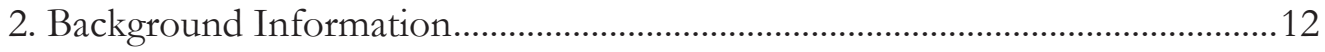

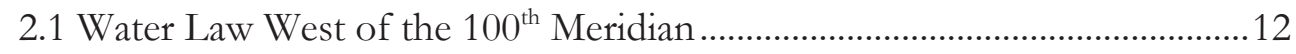

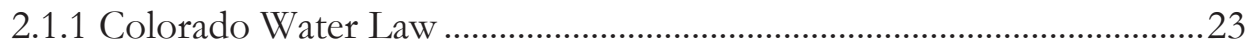

2.2 Water Infrastructure in the American Southwest.........................................29

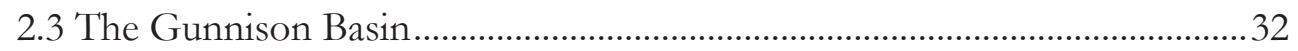

2.4 Climate Change in the Colorado River Basin .................................................37

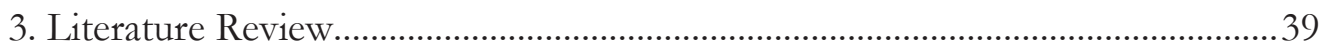

3.1 Colorado River Basin Water Management........................................................ 39

3.2 Environmental Policy and Data....................................................................... 40

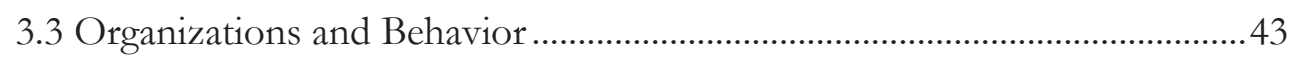

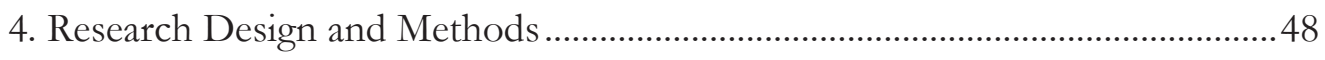

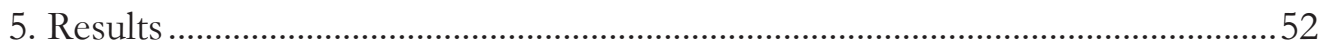

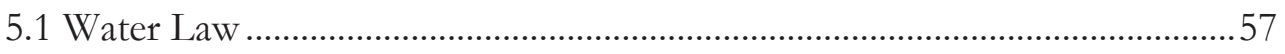

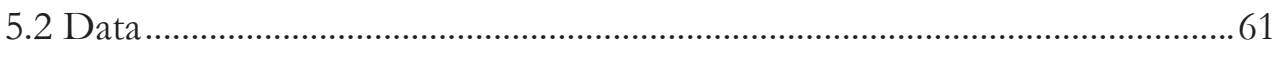

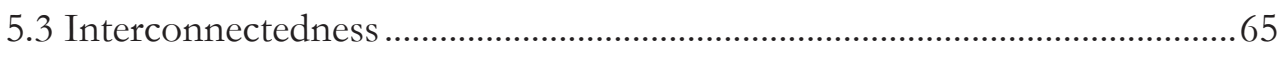

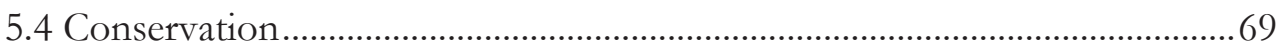

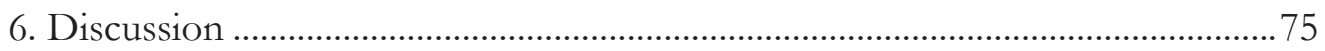




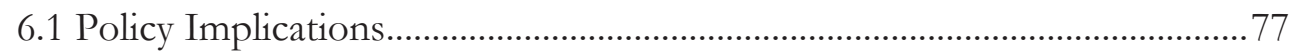

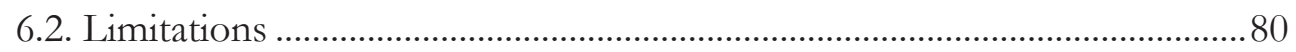

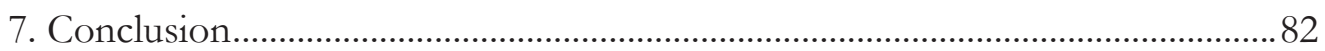

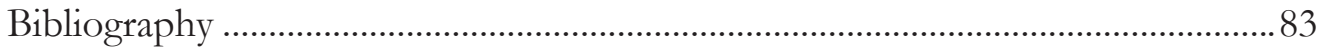

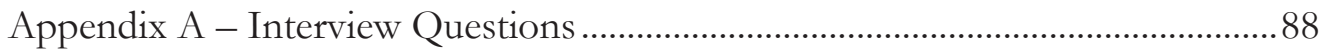

Appendix B - Text of Informed Consent ……...................................................... 89

Appendix C - Data Dictionary ........................................................................... 92

Appendix D - Copyright Permission .......................................................................100 


\section{List of Figures}

Figure 1: Supply and Demand Gap Chart from U.S. Bureau of Reclamation, (Dec. 2012).

Colorado River Basin Water Supply and Demand Study, U.S. Department of the Interior, Government Printing Office: Washington, D.C.

Figure 2: Colorado River Basin, U.S. Bureau of Reclamation, (Dec. 2010). Colorado

River Basin Water Supply and Demand Study, U.S. Department of the Interior,

Government Printing Office: Washington, D.C........................................................ 15

Figure 3: Gunnison Basin Snowpack from NCRS, March 20,2015.

http:/ /www.nrcs.usda.gov/wps/portal/nrcs/detail/co/snow/products ............. 30

Figure 4: Teacup diagram showing reservoir levels in the Gunnison Basin (February 22,

2015). U.S. Bureau of Reclamation

(http://www.usbr.gov/uc/water/basin/tc_gr.html). 34

Figure 5: Black Canyon of the Gunnison. Photo: Rhianna Williams 2013........................ 35

Figure 6: Dust on Snow near Coal Mountain Pass. (2013) Photo: R. Williams................... 37

Figure 7: Flow chart of data as it is filtered by beneficial use as defined by water law (R.

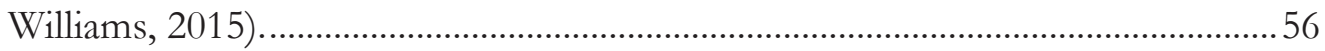

Figure 8: Simplified flow chart of organizations municipalities and water Districts

regularly interact with or report water data too. Each entity is nested within a

regional, state or federal framework. (R. Williams, 2015).

Figure 9: Water from the Taylor Reservoir owned by the UVWUA flows through the

Bureaus Aspinal Unit and Gunnison Tunnel where it is exchanged on paper for water out of the Ridgway Reservoir over 30 miles away.

Figure 10: Task Environment of Water Managers. Water Managers exist in an outer, sphere of the organization in which they work with many people inside and outside of the organization to ensure continued access to water rights.....

Figure 11: Residential water pump for town ditch in City of Gunnison, CO. Photo:

Rhianna Williams 2014. 


\section{Acknowledgements}

I would like to thank my Advisor Richelle Winkler for being flexible with my project proposals and her assistance in my studies and encouragement in my research. Thank you also to my committee who gave me great feedback on how to improve my research and writing.

For my husband, Robert Narhi, who has shown tremendous patience throughout this process and came to adventure with me on occasion while I spent over a year in Colorado. Thank you to my family who has supported my continuing education efforts.

To everyone with whom I interviewed in Colorado, I appreciate the time you all took to speak with me and answer my questions as they came up both during and after the interviews. Thank you to Agnieszka Prezilowska, my supervisor at the Uncompahgre Watershed Partnership; I appreciate how supportive you were of my research and workload at the UWP. Thank you also to my supervisor, at the Gunnison Basin and Grand Valley Selenium Task Force, Sonja Chavez de Baca, for showing me the world of inter-agency cooperation. 


\section{Abbreviations}

$\begin{array}{ll}\text { AWWA } & \text { American Water Works Association } \\ \text { CAP } & \text { Central Arizona Project } \\ \text { CWCB } & \text { Colorado Water Conservation Board } \\ \text { CFS } & \text { Cubic Feet Per Second } \\ \text { CRCD } & \text { Colorado River Conservation District } \\ \text { CRSP } & \text { Colorado River Storage Project } \\ \text { BOR } & \text { U.S. Bureau of Reclamation } \\ \text { GBRT } & \text { Gunnison Basin Round Table } \\ \text { MAF } & \text { Million Acre Feet } \\ \text { Tri-County } & \text { Tri-County Water Conservation District } \\ \text { USFS } & \text { U.S. Forest Service } \\ \text { USGS } & \text { U.S. Geological Survey } \\ & \text { Uncompahgre Valley Water Users Association } \\ & \end{array}$




\section{Abstract}

In the American Southwest, a growing population combined with climate change induced weather pattern changes are creating growing conflict for uses of the over appropriated Colorado River System. Water managers use a variety of tools and data to make decisions at the local and regional level which will impact access for future users. The purpose of this study is to understand how water managers use data and knowledge to manage current and future access to water resources in a water scarce region. A case study of the Gunnison River Basin located within the larger Colorado River Basin was conducted over 14 months. Information was collected in the form of regional documentation, participant observation, and interviews of nine regional water professionals. Gathered data was analyzed throughout the collection process using the theory building and testing methods of grounded theory. Rather than directly informing management, findings indicate that the use of data is mediated by the social institution of water law and its associated social norms, organizations, and bureaucracy. 


\section{Introduction}

With the exception of the rainforests of the Pacific Northwest, annual precipitation rates decrease dramatically west of the $100^{\text {th }}$ meridian in the contiguous United States. Governed by an annual cycle of snow accumulation in the winter followed by rapid mountain runoff in the spring; rivers in the west like the Colorado River go from a raging, scouring flood in the spring to little more than a trickle in the fall. In some cases, riverbeds go dry in the winter as mountains gather snow for the spring melt. Water management in this water scarce environment requires knowledge of the resource, the environment in which it occurs, competing uses, and the law that governs it.

Throughout the Colorado River Basin, a complex system of dams, reservoirs, and canals manage the delivery of water for use in agriculture, mining, manufacturing, and municipal growth (Reisner, 1986). This complex infrastructure is mirrored in the region's legal structure governing water. Early settlers found that the riparian water laws of the eastern U.S. were unsuited to govern the scarce water supply in the West. In order to fairly allocate water resources, they adapted existing mining law to regulate water creating the prior appropriation framework. The prior appropriation system gives priority to those who first develop a water right by putting stream water to 'beneficial use' as defined by law and is commonly referred to as, "first on site, first in right," in conversation (Grantham, 2011; Phillips Whitmore, 2013). The legal commodification of water, combined with the 1922 Colorado Compact which allocates the Colorado River among seven basin states, form the basis of the laws, regulations, and agreements that make up the 'Law of the River' which governs water in the West.

Within the Colorado River Basin, traditional management methods of water resources are being challenged as changes in climate, population, and knowledge of the hydrological cycle are creating regional awareness of impending conflict between users as demand exceeds supply (Kuhn, 2014; Udall, February 27, 2014). The phenomenon of dust on snow, which causes snow accumulation to melt earlier, creates storage problems as reservoirs have no room to store the runoff earlier in the year. Fourteen years of 
drought have depleted Lake Mead and Lake Powell to their lowest levels since first filling in the 1950's. Further depletion of the reservoirs may trigger legal action among the states according to the 1922 Colorado River Compact requiring Upper Basin states to curtail water use and stretch already parched water resources.

Climate change is expected to exacerbate regional drought. Water is over allocated in the basin, in excess of $10 \%$ of the average supply by some accounts, and demand is expected to exceed supply by 2050 in the Colorado River Basin (Figure 1) (Bureau of Reclamation, December 2012).

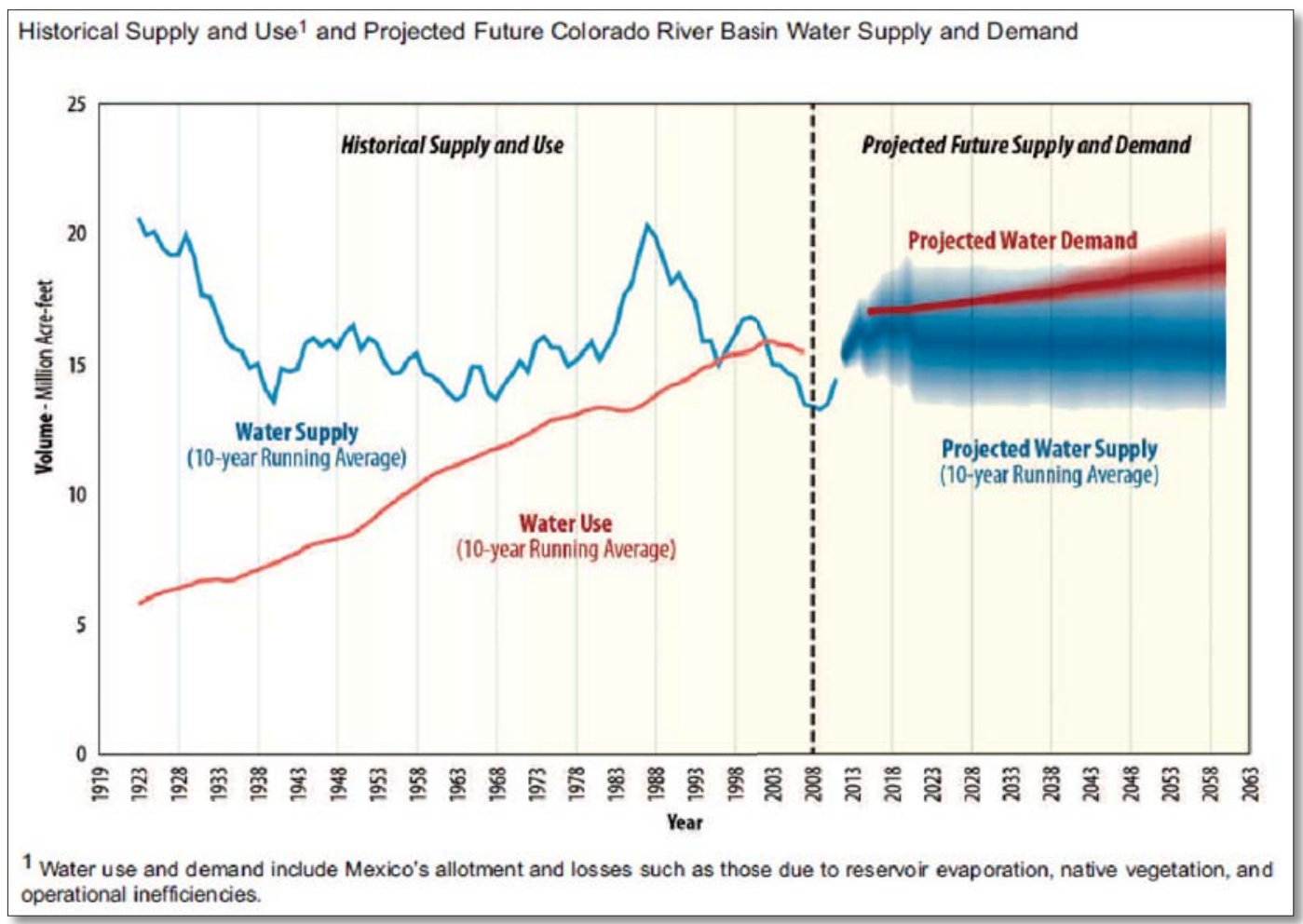

Figure 1: Supply and Demand Gap Chart from U.S. Bureau of Reclamation, (Dec. 2012). Colorado River Basin Water Supply and Demand Study, U.S. Department of the Interior, Government Printing Office: Washington, D.C.

Figure 1 shows water use and supply charted in million acre-feet on the y-axis and year on the x-axis. An acre-foot of water is approximately enough water to cover a football field (minus the end zones) with one foot of water, or 325,851 gallons (Sibley, 2012). Starting with the wet years of 1932, historical supply is charted against demand, which rises with in migration until the drought of 2002. Demand is seen to dip for the 
first time as drought restrictions are brought into effect. However demand is expected to continue increasing as the region continues to grow. The projected demand and supply range is depicted as blurred red and blue line.

Knowledge of how the hydrological system works, water availability, and drought cycles is continually refined based on data that is perpetually collected, analyzed and published on area climate, and water resources. For instance, we are only recently beginning to get a scientific understanding of the potential impacts of climate change. However, water policy has been built upon a century of water law and related institutions, relationships, and social norms. In this context, are scientific knowledge and data being used at the local level in the management process? Are managers adjusting operations based on new information?

This research investigates how data is used by local water managers for operations and policy by conducting a case study in the Gunnison Basin of Colorado. Located within the Colorado River Basin and on the Western Slope of the state of Colorado; this basin includes federal, state, and local projects and faces issues of supplying water to its own residents as well as satisfying quantity and quality agreements for water delivery downstream. Using the grounded theory method, I lived in the area for over a year, and participated in local water culture by working for a local watershed group, attending conferences, and meetings, collecting documents, and conducting interviews of local water managers. This process allowed for examination of the environment and people that use water data at the local level. Throughout, I pay particular attention to social, cultural, and legal contexts within which water management decisions are made. 


\section{Background Information}

"The river runs downhill from its source in the Rockies, but it also follows another cardinal rule: in the American West water flows toward money and power."

-Timothy Egan

\subsection{Water Law West of the $100^{\text {th }}$ Meridian}

\section{"Whiskey is for drinking, water is for fighting" _ - Mark Twain}

When the original thirteen U.S. colonies were formed, the land was found to have similar climate and water resources to England. So along with other English common law, colonists also transferred English riparian law to the new world to govern their water resources (Johnson \& DuMars, 1989). This law viewed rivers as an amenity which enhanced surrounding land. Navigable waters were owned by the crown and available to the public for fishing and travel (Johnson \& DuMars, 1989). The rights to non- navigable waters were held by riparian landowners who were entitled to use the free flowing water as long as it did not diminish the ability of other riparian landowners to use the same stream (Dravnieks Apple, 2001; Merchant, 2002).

On the western side of the North American content Spanish explorers, with experience diverting rivers in arid Spain, settled areas in what is now the American Southwest and Mexico. Farming settlements built around Catholic missions served the purpose of "civilizing" the indigenous peoples, while making use of their labor and land to support Spanish mines and military bases (Dravnieks Apple, 2001; Johnson \& DuMars, 1989; Wilkinson, 1992). Spaniards used existing canals dug by indigenous peoples or created their own to irrigate crops for food and fiber (Johnson \& DuMars, 1989).

In this water scarce environment, the Spaniards transferred their own laws for water management to the new world. In contrast to English riparian law, all water in Spain is owned by the crown; priority for water use went to the community first. Individuals could gain the right to use water only after community needs were met (Dravnieks Apple, 2001; Wilkinson, 1992). This legal system of water management 
continued until the U.S. acquired what is now the American Southwest. Between the end of the U.S.-Mexican War and the ratification of the Treaty of Guadalupe Hidalgo, the newly acquired territory was flooded by American prospectors lured west by the California gold rush of 1848 (Reisner, 1986; Wilkinson, 1992).

As mining became the major industry in the area, water use for mining increased, and water was diverted away from the stream to off stream mining claims (Wilkinson, 1992). The early American prospectors arrived in an area of transition: the U.S. hadn't established a strong federal presence, but the Mexican government was already gone (Hundley, 1975; Wilkinson, 1992). The ensuing legal vacuum allowed the prospectors to set up their own rules and procedures using a combination of Spanish law, riparian law, and "common sense" mining customs to divvy up the land; Congress was content to let them do so (Hundley, 1975; Wilkinson, 1992). In this way, they set up a "first come, first served" rule for land and water that would later be officially adopted at the local and state level through a series of legislation and lawsuits that would become prior appropriation (Dravnieks Apple, 2001; Grantham, 2011; Johnson \& DuMars, 1989).

Today, prior appropriation is regulated by state and how it is applied varies from state to state. Some states, like California and Kansas, have a mix of riparian and prior appropriation laws to regulate water use where drier states, like Colorado, only use prior appropriation (Johnson \& DuMars, 1989; Rice \& White, 1987). With the application of prior appropriation to the distribution of water, water rights are treated as a commodity and separated from the land. In this way, water can be bought and sold apart from the land it flows on and is free to be used elsewhere (Grantham, 2011). Like the Spanish law before it, water is owned by the state, water rights only give an individual the right to use water, not ownership of the water itself (Getches, 2001; Grantham, 2011).

Prior appropriation has two goals, the first is to make sure all water is being put to beneficial use; the second is to create an ordered system for water distribution in times of drought (Grantham, 2011; Johnson \& DuMars, 1989). Commonly referred to as "first on site, first in right," the person who first diverts water from the stream and puts it to "beneficial use", as defined by law, is said to have "perfected their water right" and may file for a "water decree" (Grantham, 2011). This water decree gives the holder the 
right to use a certain amount of water per year as well as a ranking within the list of water rights holders (Grantham, 2011). Water rights holders are either senior or junior to other rights holders on a stream or river; in times of water scarcity those with Senior Rights may place a "water call". Those with junior water rights must reduce the amount of water diverted until the senior user receives their full right (Grantham, 2011; Rice \& White, 1987). These rules apply to any entity that owns a water right (Grantham, 2011).

As the western states were established, each claimed to own the water flowing within their boundaries; they codified this claim through state constitutions and in legal statutes (Getches, 2001). However there was no interstate law governing water and many rivers crossed multiple state boundaries. This resulted in a number of lawsuits between the states over their ability to use water (Hundley, 1975). This conflict between the states grew with their populations which mushroomed after the passage in the Reclamation Act in 1902 (Wilkinson, 1992). Hundreds of thousands of settlers moved in to claim millions of acres of newly irrigated land under the Homestead Act. The influx of settlers reached its peak in 1913 when 23 million acres of land was patented (Hundley, 1975; Wilkinson, 1992).

The development of water law and water projects goes hand in glove. As more and more settlers diverted water from the streams to irrigate their fields, battles over the use of water became more contentious. Colorado, the headwaters state for many rivers in the west, including the Arkansas, Colorado, and Rio Grande Rivers, entered into lawsuits with both Kansas and Wyoming over the use of interstate waters (Dravnieks Apple, 2001; Hundley, 1975). The downstream states of Kansas and Wyoming had grown uneasy over the growth in Colorado and were worried Colorado's growth would harm their own by reducing the available water coming downstream. While the Supreme Court dismissed Kansas's suit against Colorado, the Court found that the law of prior appropriation applied between states in the case Wyoming v. Colorado (Gallaher, Heikkila, Patterson, Frank, \& Weible, 2013; Hundley, 1975). This ruling led to a flurry of new water projects as states scrambled to claim water rights ahead of others by putting water to beneficial use (Gallaher et al., 2013). Figure 2 shows the drainage area of the 


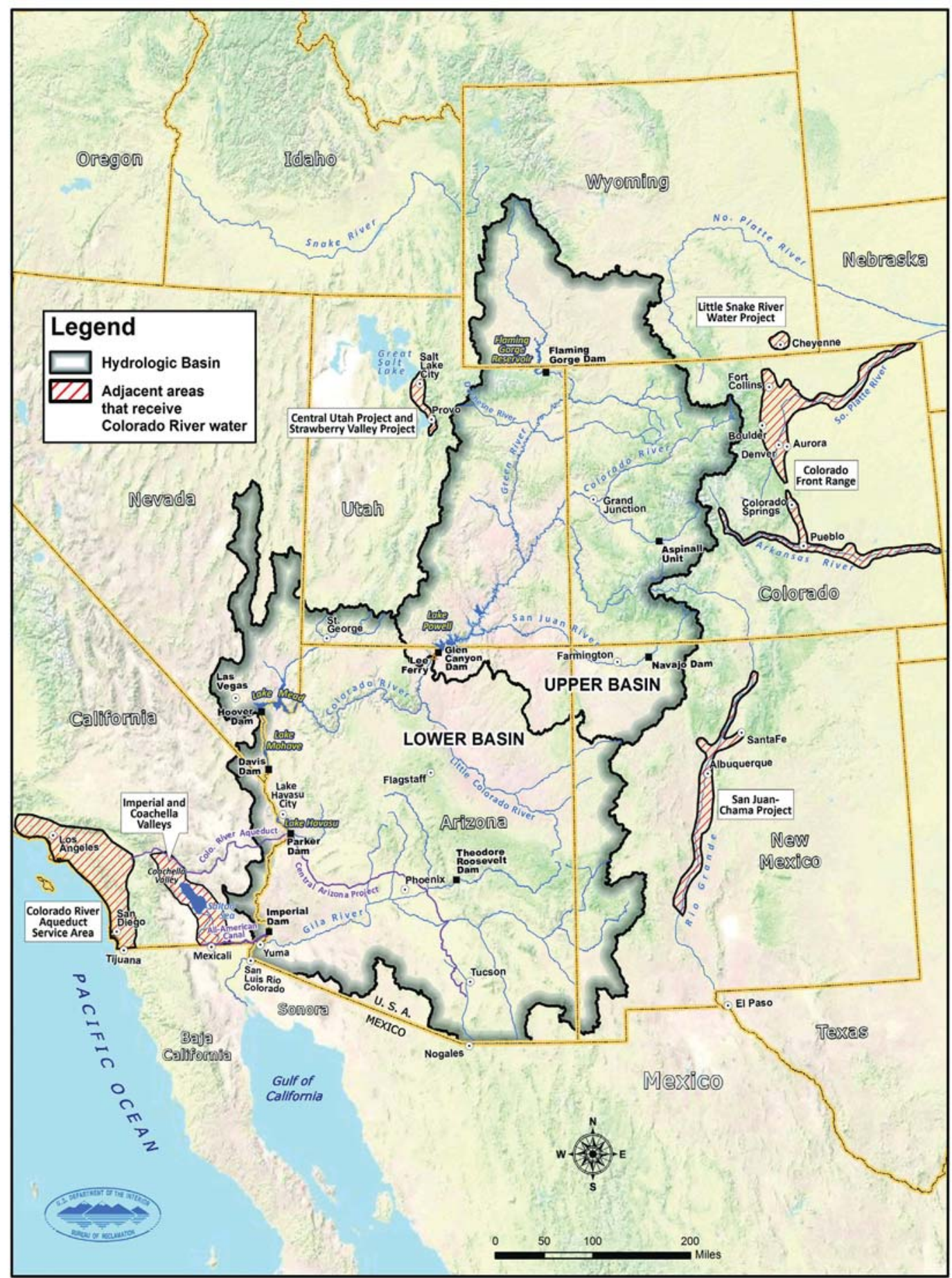

Figure 2: Colorado River Basin, U.S. Bureau of Reclamation, (Dec. 2010). Colorado River Basin Water Supply and Demand Study, U.S. Department of the Interior, Government Printing Office: Washington, D.C. 
Colorado River Basin and the seven states it supplies with water. Areas shaded with red stripes show outer basin areas which import Colorado River water to support agriculture and urban growth.

The rights to the water in the Colorado River which flows through some of the driest land in the United States and supplies water to seven states and two countries became the object of what was to become a monumental interstate compact and the foundation for the "Law of the River." Two water projects in particular became a source of motivation for the creation of the 1922 Colorado River Compact: the All American Canal in the Imperial Valley of California and the Hoover Dam in the Boulder Canyon area of Arizona and Nevada (Hundley, 1975). Both projects raised questions about interstate water rights, rights to revenue from hydropower, and the question of who should build them: private companies, states, or the federal government (Hundley, 1975; Reisner, 1986).

It was this convergence of factors: increasing competitive development, costly lawsuits, and a fear of federal regulation of western waters that finally led the states of the Colorado River Basin to come together to negotiate their own interstate water law (Hundley, 1975). Appointed commissioners from Colorado, California, New Mexico, Utah, Nevada, Arizona, and Wyoming along with the Secretary of the Interior convened as the Colorado River Commission to develop an interstate agreement. After eleven months of meetings and negotiations the Colorado River Commission produced the Colorado River Compact on November $24^{\text {th }}, 1922$ for ratification by the seven basin states (Hundley, 1975; Reisner, 1986).

The Colorado River Compact would become the foundation of a collection of laws, statutes, international treaty, project operating rules, and case law known as the "Law of the River" (Hundley, 1975; Reisner, 1986; Udall, 2014). This historic interstate agreement divided the Colorado River Basin into an Upper and Lower Basin using the point of Lee's Ferry in Arizona as an imaginary dividing point (Hundley, 1975; Reisner, 1986). The four Upper Basin states consist of Wyoming, Colorado, Utah, and New Mexico. The Lower Basin is California, Arizona and Nevada (Reisner, 1986). Data on flow had been collected from flow gauges along major points of the Colorado between 
1899 to 1920 which found average flow at Lee's Ferry to be about 16,400,000 (Hundley, 1975; Miller \& Rhodes, 1997; Reisner, 1986). In good faith, the commissioners of the Colorado River Commission used the data presented by the Bureau of Reclamation for negotiation (Hundley, 1975; Udall, 2014).

However, due to equipment problems and a series of unseasonably wet years, the measurements greatly overestimated river flow (Hundley, 1975; Reisner, 1986). The Upper and Lower Basin were each apportioned 7,500,000 acre-feet per year; though Article III (b) allows the Lower Basin to increase its consumptive use by an additional 1,000,000 acre-feet per year (Hundley, 1975; Miller \& Rhodes, 1997). The Upper Basin is required to deliver 75,000,000 acre-feet of water to the Lower Basin at Lee's Ferry over a ten year period. Failure to provide $75,000,000$ would result in a "curtailment" of Upper Basin water resources until the promised water is provided to the Lower Basin (Hundley, 1975). In addition, the Colorado River Commission agreed that water for any treaty with Mexico should come from "surplus" Colorado River water; the commissioners suggested 600,000 acre-feet (Hundley, 1975). The 1922 Compact did not apportion water to each state, nor did it address the water rights of Native American Tribes (Hundley, 1975; Miller \& Rhodes, 1997). These issues would be addressed later through laws, lawsuits, and additional compacts.

When the Colorado River Compact was presented in each state for ratification in November of 1922, political battles and arguments ensued. By February $1^{\text {st }}$, 1923, six states had ratified the compact; only Arizona stubbornly refused to ratify the compact (Hundley, 1975). Arizona mainly feared that water development in California would prevent the development of its own resources. In addition, Arizona objected to the Hoover Dam Project on its land, it also wanted a guarantee for access to hydropower from the dam if it was constructed, an aqueduct for the delivery of water to central Arizona for irrigation, and for Gila River flow to not be included in the flow totals of 1922 Compact (Hundley, 1975).

Federal projects in the Colorado River Basin could not proceed until water had been apportioned by state, and California wanted the construction of Hoover Dam for flood control and storage as well as construction of the All American Canal in the 
Imperially Valley for irrigation (Hundley, 1975; Reisner, 1986). In an attempt to assert its own rights over water and curb California's, Arizona decided to appeal to the Supreme Court on the basis that California's development was harming Arizona development (Hundley, 1975; Johnson \& DuMars, 1989; Reisner, 1986).

Arizona made appeals to the Supreme Court in 1930, 1934, and 1935; all were rejected (Hundley, 1975). After its last appeal to the Supreme Court, Arizona continued to stubbornly refuse to ratify the compact for eight more years (Hundley, 1975). Until the compact was ratified and water appropriated, the federal government would not build water projects in the area. In order to get around Arizona's stalling, Colorado, California, Nevada, Utah, Wyoming and New Mexico decided to ratify a six state compact. The Upper Basin States believed doing so would protect them from development in California by allowing them to proceed with their own water projects while also allowing Arizona to enter at a later date (Hundley, 1975). The six state compact was sent to Congress for ratification.

Ratification of the 1922 Compact was folded into the Boulder Canyon Act, which gave Congressional authorization for the construction of Hoover Dam (Miller \& Rhodes, 1997; Wilkinson, 1992). An amendment to the bill from Key Pittman of Nevada proposed apportionment of the Lower Basin waters: 300,000 acre feet for Nevada, 4,400,000 acre-feet for California, and 2,800,000 acre-feet for Arizona, which would go into effect if the Lower Basin states, including Arizona, agreed to it (Miller \& Rhodes, 1997). Furthermore, the legislation would give Arizona and California equal rights to the "surplus" waters not apportioned by the 1922 Compact and gave Arizona exclusive rights to the Gila River (Miller \& Rhodes, 1997). Once passed through Congress, President Herbert Hoover issued a proclamation declaring the Boulder Canyon Act and 1922 Compact effective on June 25, 1929 (Hundley, 1975).

Arizona continued making appeals to the Supreme Court against California until it saw a larger threat in the February $3^{\text {rd }}, 1944$ treaty with Mexico. Making an abrupt about face from twenty-two years of refusal, Arizona ratified the 1922 Compact on February 24, 1944. Barely two months later the United States ratified the treaty with Mexico, awarding Mexico 1,500,000 acre-feet of Colorado River water (Hundley, 1975). 
The states of the Upper Basin, which were growing much more slowly than California or Arizona, didn't agree to state water apportionments until 1948. The move to apportion the water was spurred by a 1946 report from the Bureau of Reclamation in which the Bureau found that there was not enough water for all of the projects proposed for the Upper Basin (Hundley, 1975; Miller \& Rhodes, 1997). In addition, federal projects could not move forward until the states had appropriated their water. Over the next two years the states gathered technical data on the river and their needs which they brought to a conference in Vernal, Utah, July 1948 (Hundley, 1975). By this time they realized that average river flow was smaller than the 15,000,000 acre-feet negotiated in the 1922 Compact (Wilkinson, 1992). Since they could not be sure how much water would be left to the Upper Basin after they met the delivery requirement to the Lower Basin apportionments were made in percentages (Hundley, 1975; Wilkinson, 1992). Colorado received 51.75\%, Utah 23\%, Wyoming 14\%, New Mexico 11.25\%, and a flat 50,000 acre-feet to Arizona since a very small portion of the state was in the Upper Basin (Hundley, 1975).

In the Lower Basin, Arizona and California still had not agreed on the apportionment suggested by Key Pittman of Nevada, and construction of further reclamation projects could not move forward until an agreement was made (Hundley, 1975). In a bid to settle the differences of water and to get the Central Arizona Project (CAP) aqueduct approved Arizona once again sued California and appealed to the Supreme Court in 1952 (Hundley, 1975; Reisner, 1986). By this time California was already diverting over 4,400,000 acre-feet of water and Arizona believed it could prove that California water diversions were harming Arizona development (Hundley, 1975). The historic case of Arizona vs California et al. (1963) lasted eleven years and nearly $\$ 5$ million dollars before the court announced its opinion on June 3, 1963 (Hundley, 1975). Once again, data on average flow was collected, this time by a special master for the court, using improved measuring equipment and data from 1922 to 1956. Now it was found that virgin stream flow at Lee's Ferry was about 14,000,000 acre-feet, 2,400,000 acre-feet less than what the 1922 Compact is based on (Hundley, 1975). 
While Arizona won the case, the court opinion also was a small victory for the water rights of Native American tribes in the basin (Dravnieks Apple, 2001; Hundley, 1975). Arizona v. California et al (1963) codified a number of decisions which would impact projects on the river, and apportionment. First, the Supreme Court affirmed the Lower Basin apportionment proposed by Pittman of Nevada and enacted the Boulder Canyon Act (Hundley, 1975). Then, it awarded Arizona the exclusive water rights to the Gila River, except for the small portion of the river flowing within New Mexico (Hundley, 1975). In addition, the waters of the Gila River were not to be a part of the 7,500,000 acre-feet allocated to the Lower Basin. The exemption of the Gila River Flow from the 1922 Compact totals increased the burden of water delivery at Lee's Ferry on the Upper Basin (Hundley, 1975). Administratively important was the court's decision that in the event of a natural disaster, in which there is not enough water to provide for all claims on the river, the Secretary of the Interior would apportion water (Reisner, 1986). Finally, the court established that rights perfected prior to the 1922 Compact had to be satisfied before any post-1922 Compact rights were fulfilled (Dravnieks Apple, 2001; Hundley, 1975; Johnson \& DuMars, 1989).

By establishing the priority of pre-1922 Compact rights the Court had strengthened the findings of the 1908 case of Winters $v$. U.S. (Hundley, 1975; Johnson \& DuMars, 1989). In Winters v. U.S. the Court gave rights to the five reservations along the mainstream of the Colorado River. In what is now referred to as the Winter's Doctrine, the court determined that when the U.S. government placed the tribes on reservations it was assumed that water resources were needed not only for domestic use and crops, but also to sustain the existing wildlife and vegetation Native Americans used to survive (Hundley, 1975; Reisner, 1986). Thus, reservation water rights dated back to the time of the formation of the reservation, between 1865 and 1917(Hundley, 1975). So, not only did reservations have rights to developed and undeveloped water, all of their rights are pre-1922 Compact and are to be given priority in times of natural disaster (Hundley, 1975; Miller \& Rhodes, 1997; Reisner, 1986). According to the Arizona v California 1963 ruling, in addition to the Winters Doctrine, the water used on reservations is taken from the state's apportioned amount (Hundley, 1975). 
By 1963, many details left out of the 1922 Compact had been determined or discovered: there was less water on average than originally negotiated, the waters of the Gila River did not count toward the 15,000,000 acre-feet of the 1922 Compact, reservations had rights to state water, water had finally been appropriated by state, and Mexico also had rights to Colorado River Water (Hundley, 1975; Johnson \& DuMars, 1989). The waters of the Colorado River were over-appropriated even by 1922 Compact standards and later tree ring studies have shown average flow on the Colorado to actually be 13,000,000 acre-feet (Wilkinson, 1992).

Based on new data of average stream flow, the Upper Basin could not rely on annual streamflow to provide the Lower Basin with their apportioned water. In the midcentury however, the Upper Basin could rely on two things to ensure the Lower Basin received their allotment. First, the construction of the storage projects of Hoover Dam and Glen Canyon Dam eased the delivery requirements of the Upper Basin by leveling out water delivery to the Lower Basin. Second, in 1963 the Upper Basin had yet to use its full allotment of water, creating an artificial surplus of water to flow downstream. Beginning in the 2000's however, Colorado has used more than its apportioned amount, and severe drought has strained the water reserves in Lake Powell and Lake Mead (Kuhn, 2014; Mimiaga, 2014).

In addition, there have been several federal acts which have further mediated water allocation and project operations. Those laws include the Colorado River Storage Project Act of 1956 (CRSP) and the Colorado River Basin Project Act of 1968(Kenny, Bates, Bensard, \& Berggren, 2001). The CRSP provided for the development of storage projects in the Upper Basin which continue to assist the Upper Basin meet their 1922 Compact delivery requirements while allowing the Upper Basin to develop their water allocations. These water projects include the Aspinall Unit in the Gunnison Basin (Getches, 2001; Kenny et al., 2001).

Arguably, the Federal laws of the twentieth century with the greatest impact on water uses in the west include the National Environmental Policy Act, the Clean Water Act and the Endangered Species Act (Bell, 1997; Johnson \& DuMars, 1989; Wilkinson, 1992). The Endangered Species Act protects in-stream flow and river habitat and 
includes in-stream uses as a "beneficial use", which would have been unthinkable in the early development of prior appropriation (Dravnieks Apple, 2001; Getches, 2001;

Reisner, 1986). As part of a growing awareness of the environmental impacts of dam operations on riparian ecosystems the Grand Canyon Act of 1992 required that Glen Canyon Dam be operated in a way that reduces negative impacts on the environment and recreational uses of Grand Canyon National Park (Dravnieks Apple, 2001). The Clean Water Act alters water operations by placing limits on pollution, in the west major problems include acid mine drainage, as well as salinity and selenium from irrigation (Bell, 1997; Bureau of Reclamation, December 2012). These acts in addition to previous allocations and reduced flows have put pressure on basin states to meet all of the competing needs on the river.

Today, the west is experiencing a twelve year drought, which has tested the limits of the legal framework and physical infrastructure regulating water use. After three years of continuous drought the Secretary of the Interior directed the Bureau of Reclamation to develop strategies for coordinating competing water uses on the Colorado River Basin (Bureau of Reclamation, December 2007). Reclamation solicited data and input from a variety of stakeholders including the basin states, Native American tribes, NGOs, and the general public, to deliver a Final EIS based on a range of alternative scenarios (Bureau of Reclamation, December 2007; Jerla, 2009). The basin states agreed to the "Colorado River Interim Guidelines for Lower Basin Shortages and Coordinated Operations for Lake Powell and Lake Mead" (Interim Guidelines) and a Record of Decision was issued in December of 2007 (Jerla, 2009; Kenny et al., 2001). The Interim Guidelines, which expire in 2026, provide operational guidelines for Lake Powell and Lake Mead during drought and low reservoir conditions. In addition, it includes provisions to encourage efficient use of basin water and encourages conservation in the Lower Basin which would result in an Intentionally Created Surplus to reduce the possibility of future shortages (Jerla, 2009; Mulroy, 2008). Finally, like the 1922 Compact before it, the Interim Guidelines include the hope that the basin states will turn to negotiation and cooperation in order to prevent costly and lengthy future litigation (Jerla, 2009). 
Operations of the Colorado River Storage Project were further amended with the adoption of Minute 319. This treaty provided for storage of Mexico's water allocations in Glen Canyon Dam after an earthquake damaged the country's own storage system. It was also this agreement which, in 2014, allowed the Colorado River to flow to Colorado Delta for the first time since 1996 (Waterman, 2010).

While the 1922 Compact is a historical interstate agreement, it is also only the beginning of interstate and federal oversight of the Colorado River. Since its first inception in the early 1900's, its scope has broadened to include new beneficial uses not first considered by the area's early mining camps or Colorado River Commission. It is important to recognize the "Law of the River" as a continually evolving agreement between the seven basin states of the Colorado River and the federal government, not a static and unchanging historical artifact. While data and public opinion continue to be solicited for agreements and lawsuits, the law continues to impact how money is spent, what projects are built, and how projects are operated in the Colorado River Basin.

\subsubsection{Colorado Water Law}

"Coloradans, in fact, share a genius for creating local government districts to bump up against others, daring good ideas to emerge when bad tempers are ultimately frustrated by the inability to get anything done."

\section{- Gregory J. Hobbs Justice, Colorado Supreme Court}

Colorado law is based on prior appropriation (Grantham, 2011; Hobbs, 2004). The Territorial Supreme Court broke away from traditional riparian law soon after the Colorado Territory was formed with the ruling of Yunker $v$. Nicols (Hobbs, 2004). The court found that the arid climate of Colorado made the diversion of water from natural streams necessary for survival and economic growth (Hobbs, 2004). Congress acknowledged states' and territory's right to regulate unappropriated water on their own, as well as federal lands, through the passage of the Mining Act of 1866, and the Desert Lands Act of 1977 (Gallaher et al., 2013; Hundley, 1975). 
When Colorado ratified it's constitution in 1876, it made prior appropriation the law of the state; Sections 5 of Article XVI declares that the water of streams are public property (Gallaher et al., 2013; Grantham, 2011). Section 6 of Article XVI declares that, "the right to divert the unappropriated waters of any natural stream to beneficial uses shall never be denied," and defines the priority of preferred uses in times of drought (Grantham, 2011; Hobbs, 1997). The water law framework that was developed on the foundation of prior appropriation became known as the Colorado Doctrine (Hobbs, 2004).

In order to document and administer water rights the Colorado legislature established ten water districts based on major watersheds in 1879 (Gallaher et al., 2013). Each district was managed by a commissioner who allocated district water according to prior appropriation. Water rights claimants filed claims declaring how much water they had appropriated with the commissioner. Using the self-reported amounts of water to issue water rights, many streams were quickly over appropriated (Hobbs, 1997). Two years later, the legislature established the Office of the State Engineer to monitor and document stream flow, over time the water districts became seven water 'divisions' in which Division Engineers oversaw the work of water commissioners in each division and work with the Water Court to settle disputes over water rights (Gallaher et al., 2013).

Initially, the definition of beneficial use was limited and did not include municipalities. The definition of beneficial use was changed in Colorado law after the passage of the 1902 Reclamation Act. Colorado moved to include municipalities in order to broaden the number and types of water projects that would qualify for federal assistance (Gallaher et al., 2013; Hobbs, 1997). The Reclamation Act spurred another development in Colorado: the rise of the irrigation district, water conservancy districts, and water conservation districts (Gallaher et al., 2013). These organizations and quasigovernment organizations were empowered by the general assembly to enter into partnerships with the Bureau of Reclamation in order to build reclamation projects and impose taxes to pay for projects and administration (Gallaher et al., 2013). Early projects were designed to increase irrigation usages, such as the Uncompahgre Project in the Gunnison Basin, built through a partnership between Reclamation and the 
Uncompahgre Valley Water Users Association (Hobbs, 1997; Pratt, 2010). Other Reclamation projects diverted water from the wetter Western Slope to the drier, but more populous, Front Range.

The Continental Divide runs north to south through the Rocky Mountains geologically halving the state in two. On the west side is Colorado's Western Slope, which is a rural landscape of mining, ranching, and agriculture and where most of the state's water is. To the east is Colorado's Front Range where the urban centers of Denver and Colorado Springs reside. A common saying in Colorado is that $85 \%$ of the water is in the West Slope and 85\% of the people are on the Front Range (R. Williams, field notes, April 11, 2014). In order to support Front Range development, thirty tunnels and ditches have been constructed in order to transport water over the continental divide for beneficial use (Winchester, 2001). In contrast to diversions of water within a basin, which can only be used for one beneficial use under the assumption that unused water will return to the stream for other uses downstream, imported or developed water from another basin may be used "to extinction" for beneficial purposes (Gallaher et al., 2013; Hobbs, 1997; Winchester, 2001).

The lawsuit of Wyoming v. Colorado was an important driver for Colorado to enter the 1922 Compact (Hobbs, 1997; Hundley, 1975). While the Court upheld the law of prior appropriation, they declared that since the uses in downstream Laramie, WY were senior with controlling water rights, they could control the development of upstream Colorado through water use (Hobbs, 1997; Hundley, 1975). Coming out of the Colorado River Compact, Colorado was allowed use of about one third of the average annual water supply, the remainder must be allowed to flow to downstream states (Sibley, 2012). In order to preserve rights to the water within its boundaries Colorado has since entered into nine interstate compacts and three equitable apportionment decrees (Hobbs, 1997; Schlager, Heikkila, \& Case, 2012).

Colorado realized that it needed to develop its water resources if it wanted to retain rights to the water within its boundaries (McDonald \& Cech, 2012). Transmountain diversions in Colorado that bring water from the wet Western Slope to the drier Front Range date back as early as the 1860's, usually in the form of small ditches 
(Winchester, 2001). In 1933 groups from the Front Range worked to divert water from the Colorado River Basin over the mountain to the Denver area. In the same way California justified its share of Colorado Water based on a higher population than the people of the Upper Basin States, Front Range officials on the project justified the diversions by arguing the more populous Front Range needed the water of the Western Slope, an argument still used today by the Front Range (Hundley, 1975; Sibley, 2012; Winchester, 2001). The Western Colorado Protective Association was formed to protect Western Slope water interests, and it blocked early attempts at a major trans-mountain diversion (Sibley, 2012).

Through continued debate in the Colorado Legislature and Congressional acts water development in Colorado moved forward. The passage of the Grand Lake Project by Congress in 1937 paved the way for the construction of the Colorado-Big Thompson Project, a trans-mountain diversion which pipes an average 220,000 acre-feet a year to the Front Range (Sibley, 2012). In order to further development of water resources in the state and cooperation of use of those resources, the Colorado Legislature passed bills to create the Colorado Water Conservation Board, the Colorado River Conservation District, and Soil Conservation Districts in 1937 (McDonald \& Cech, 2012; Sibley, 2012).

The Colorado Water Conservation Board is a state wide agency which provides policy direction for Colorado water resources. Governed by a fifteen member board with representatives from across the state, the CWCB provides technical assistance for water projects, gathers information on Colorado water, and protects state apportionments through joint work with other western state and federal agencies (McDonald \& Cech, 2012). The Colorado River Conservation District works to protect and conserve water resources for the CRCD which includes fifteen counties of the Western Slope of Colorado. Within Colorado the CRCD provides legal, technical and political representation on Colorado River issues. The CRCD is also governed by a board with representatives from each county within the CRCD (Sibley, 2012).

The use of groundwater by municipalities and irrigators grew from 1943 to 1969. Not only had these entities found that wells were an easy way to divert water, they also realized that groundwater was not subject to curtailment in the same way surface water 
was (Hobbs, 1997). That was to change, however, as knowledge of water systems grew and as groundwater diversions impaired surface diversions (Gallaher et al., 2013; Hobbs, 1997).

The Colorado Supreme Court made a presumption in 1951 that all groundwater eventually drains into surface water (Hobbs, 1997). This statement put the burden of proof that groundwater being used is not a stream tributary onto the well use (Hobbs, 1997). Later in 1969 the Colorado Legislature passed the Water Rights Determination Act which incorporated groundwater into the surface water prior appropriation system, created the Ground Water Commission to issue permits, and shifted adjudication of water rights from 80 district courts to seven new water courts (Gallaher et al., 2013).

Competing demands between municipalities and rural uses began in earnest in the 1960's when the Front Range's urban areas began a prolonged era of growth (Gallaher et al., 2013). In addition, Congress passed the Endangered Species Act, the Clean Water Act, and the Safe Drinking Water Act which put pressure on local municipalities to improve and expand water supply and treatment systems (Gallaher et al., 2013). It was these federal laws which precipitated the creation of the Project 7 Water Treatment Plant in the Gunnison Basin as the local municipalities and water districts could finance one treatment plant more easily than seven separate water treatment facilities (Project 7, 2014).

At the same time the national environmental movement was gaining support in Colorado (Gallaher et al., 2013). Laws were passed to limit overconsumption while new technologies such as water meters were employed to limit waste (Gallaher et al., 2013). In 1979, the Colorado Supreme Court recognized the ability of the Colorado Water Conservation Board (CWCB) to make and enforce minimum stream flow for the preservation of the environment (Hobbs, 1997). The CWCB is the only entity in Colorado allowed to own instream water rights.

The population of Colorado has continued to grow through the twenty first century and so have competing uses. Along with mining, municipalities, manufacturing and agriculture, there has been a continuous push to recognize instream rights for 
environmental improvement and recreation as a beneficial use (Gallaher et al., 2013; Hobbs, 2004). The passage of the Endangered Species Act, Clean Water Act, and Federal Land Policy and Management Act, with the required review and approval for waterworks has slowed and stopped the building of large storage projects in Colorado (Gallaher et al., 2013; Hobbs, 1997). In an effort to maintain water supplies for beneficial uses a diverse set of policies has been employed, these include an emphasis on demand side conservation, allowing flexibility in water transfers under prior appropriation, and the construction of small gravel pit reservoirs for water storage (Gallaher et al., 2013).

During the drought of 2003 the Colorado Legislature passed the Arkansas River Pilot Water Banking Act to authorize the use of "water banks" in the state. The ability of the CWCB to maintain instream flow was increased, allowing the board to own instream rights not just to "preserve the environment", but to actually improve the environment (Gallaher et al., 2013; Hobbs, 2004). And in 2005 the Basin Roundtables were formed through the Colorado Water for the $21^{\text {st }}$ Century Act, with the hope to increase "water supplies of Colorado by as much as 400,000 acre-feet per year" through cooperative water management (Gallaher et al., 2013).

Like the larger Law of the River legal structure, water law in Colorado has developed and changed over the years in response to competing needs and attitudes. While prior appropriation remains the foundation of the Colorado Doctrine, additional uses of and administration of water resources have changed. As knowledge of hydrology grew in the 1940s and 1950s and engineers realized the impact groundwater resources had on surface water, the state moved to apply the prior appropriation doctrine to the regulation of groundwater. Additionally, attitudes toward the environment changed, and allowances for the CWB's ability to have instream flows rights to maintain the environment were changed to allow larger allotments for instream flows to improve the environment. 


\title{
2.2 Water Infrastructure in the American Southwest
}

\author{
"When archaeologists from some other planet sift through the bleached bones of our \\ civilization, they may well conclude that our temples were dams. Imponderably \\ massive, constructed with exquisite care, our dams will outlast anything else we have \\ built - skyscrapers, cathedrals, bridges, even nuclear power plants." \\ -Marc Reisner, Cadillac Desert
}

In order to support a large population the west requires a system to store spring floods until it is needed to finish off seasonal crops in the fall. Mountains naturally capture and store water in the form of snow until spring when rising temperatures in the higher elevations melt the snowpack. The runoff naturally fills the streams until July or as late as September when streams would dry up and the cycle of snow accumulation on the mountains began again. Figure 3 charts the seasonal snowpack, in inches of Snow Water Equivalent along the y axis, for the Gunnison Basin, water year 2015 (WY2015) is the thick navy line. Along the x-axis, which charts one water year on the calendar, Snowpack begins to accumulate in mid-October and early November, peaking in April as spring temperatures begin to melt the snowpack off. As you can see in Figure 3, 2012 - 2015 have experienced less snow accumulation than average and in Water Year 2012 (WY2012), run off began a full month earlier than average. 


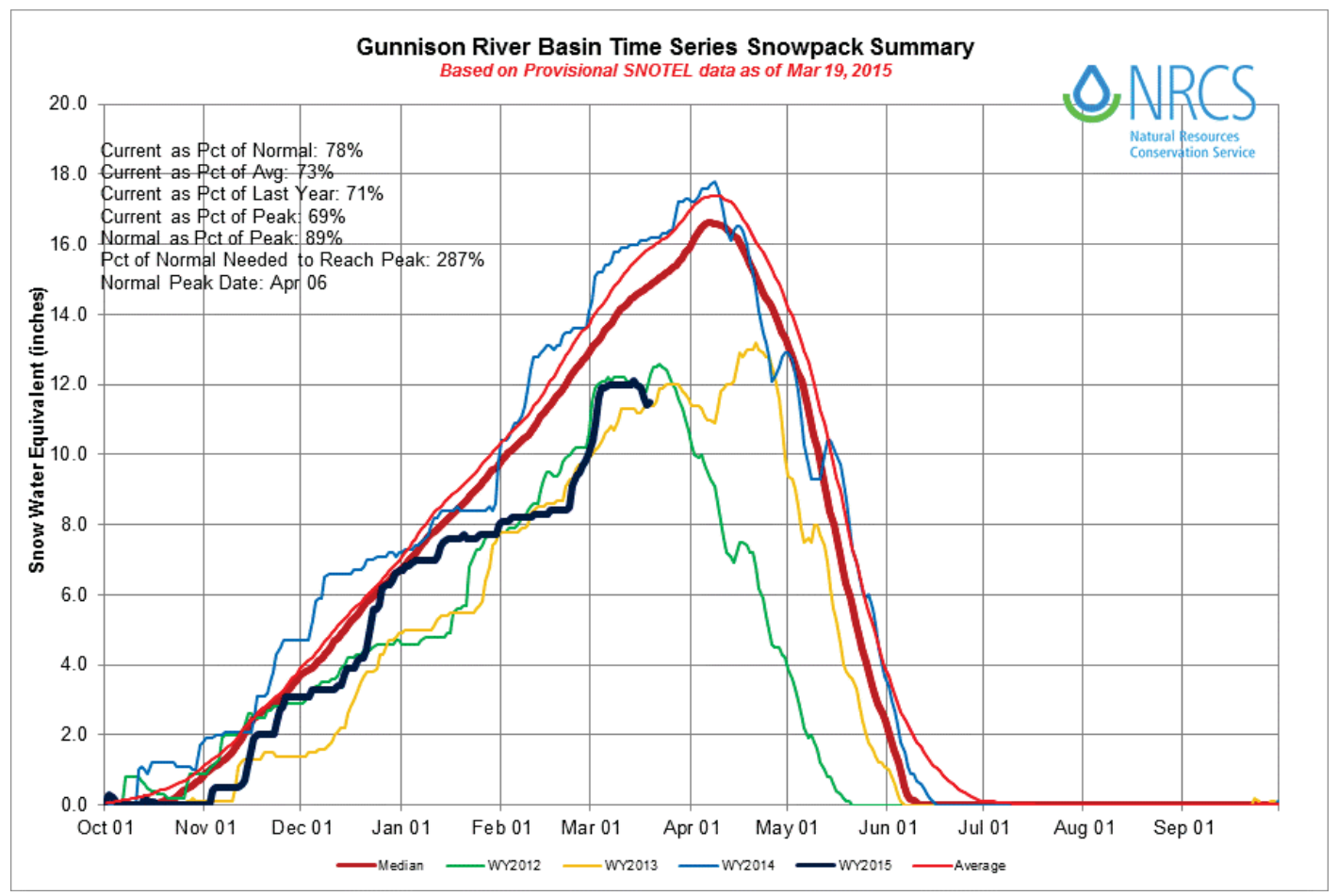

Figure 3: Gunnison Basin Snowpack from NCRS, March 20,2015.

http://www.nrcs.usda.gov/wps/portal/nrcs/detail/co/snow/products

The need to build ditches and reservoirs to supplement summer rainfall was well known to the prehistoric Hohokam, Kamia, and Cahuilla tribes in what is now Southern California, Arizona, and New Mexico (Nabhan, 1988; Wilke, Whitaker, \& Hattori, 1977). Archeologists date the earliest canal structures in the Gila-Salt region of what is now New Mexico to around 300 B.C.E. (Chomko \& Crawford, 1978). By digging ditches and canals off of rivers like the Gila and Salt, prehistoric peoples irrigated crops of squash, maize, and beans, while also harvesting fish from the canals and rivers (Nabhan, 1988).

When the Spaniards came they took over existing canals and created their own to supplement the needs of farmers and mines (Dravnieks Apple, 2001; Wilkinson, 1992). Later American prospectors created even more diversions and reservoirs to utilize the water as well as to stake claim to it. Early prior appropriation required physical control over water sources; this could be a diversion, damn or built storage; in-stream use of water did not qualify as beneficial use (Wilkinson, 1992). The demonstration of physical control allowed early regulators the ability to measure how much water was being used as 
well as determine that water was being put to "beneficial" use (Dravnieks Apple, 2001; Johnson \& DuMars, 1989).

During the time of the 1849 Gold Rush the population of California exploded. Starting in 1848 over the course of 4 years the population grew from 14,000 to 223,000 in 1852 (Wilkinson, 1992). The wave of settlers that poured into the western states created a need for a more sophisticated water delivery system than hand dug ditches. Many entrepreneurs realized they could make more money selling water than by mining and started private irrigation companies to build canals and dams (Dravnieks Apple, 2001).

In addition to developing a regional legal framework for the distribution of water, new infrastructure to store and deliver water was also built. Miners built sluices to transport water for their mining operations in the mountains, and settlers built ditches to irrigate their fields (Gregory, 1991; Smith, 2000; Waterman, 2010). In some instances neighboring farms formed ditch companies in order to maintain a common canal and ensure the continued flow of water to their own irrigation ditches (Pratt, 2010). Growing municipalities like Salt Lake City, Los Angeles, and Phoenix worked to gather water rights portfolios to feed the needs of their growing towns (Reisner, 1986).

As the land easiest to irrigate was settled and people continued to go west in search of gold or land, the need for large scale water projects grew (Reisner, 1986). In the 1870's and 1880's hundreds of irrigation companies sprung up to cater to the growing number of dry-land farmers and profit from the business of selling water. However, these companies had an average lifespan of about 10 years, and hundreds of irrigation companies were driven into bankruptcy. After fifty years of trying to reclaim the desert only 3,631,000 acres of land had been successfully irrigated by 1889 (Reisner, 1986). Neither individuals nor businesses had the resources or staying power needed to build the massive water projects required by the ever increasing population moving west.

The water problem of supply and demand was viewed as an engineering issue that required major resources (Reisner, 1986). The passage of the Reclamation Act in 1902 brought the major resources of the federal government to the west. The projects 
needed to pay for themselves through the sale of irrigation water. However the Bureau of Reclamation realized early on that irrigation water did not always pay the bills, but adding hydropower to these projects could make them profitable (Reisner, 1986). With this in mind a number of Reclamation projects included hydropower in their proposals and electricity supply for the west became intertwined with its water supply (Best, 2014; Kuhn, 2014).

Some of the largest water projects in the west continue to be operated by the Bureau of Reclamation. These projects exist to smooth out the highs and lows of available water that vary from year to year and allow the Upper and Lower Basins to develop the water allocated to them through the Colorado River Basin Compact.

Many water projects built to supply agricultural interests in the west now provide water for municipalities. Historically, Lake Mead supplied water to California, Arizona, and the desert metropolis of Las Vegas. Glen Canyon was built as a part of the Colorado River Basin Storage Project and is run in conjunction with the Aspinall Unit and Navajo Dam (Reisner, 1986). That system of dams was created to assist the Upper Basin in development of their water resources while also allowing them to fulfill their delivery obligations to the Lower Basin.

\subsection{The Gunnison Basin}

The Gunnison Basin lies on the Western Slope of Colorado and is home to the Gunnison River, second largest tributary to the Colorado River. A mix of miners, ranchers, and farmers came into the area beginning in the 1850's, forcing the Native American tribes of Utes onto local reservations and then out of the area in 1881(Pettit, 2012). In the valley areas water along the rivers was settled and farmed. The highlands around the City of Gunnison became ranching and mining land, with a copper mine to the north in Crested Butte. In addition to the silver in the San Juan Mountains, copper, coal, and the white granite of the Lincoln Memorial have all been mined or quarried from the Gunnison basin (Smith, 2000). 
Through the work of farmers to build irrigation ditches the North Fork Valley became known for their orchards of stone fruit. The Uncompahgre Valley grows alfalfa, Olathe sweet corn and more. From the beginning of settling in the Uncompahgre Valley, a reliable water supply for irrigating crops was an issue. The Uncompahgre River typically ran dry during the winter, sometimes as early as September before the crops were finished. As more people settled in the valley farmers along common canals began to form their own ditch companies to secure a reliable water supply.

Talk of bringing in water from the Gunnison River to supplement the Uncompahgre began as early as 1881(Pratt, 2010). The waters of the Gunnison were trapped in the Black Canyon of the Gunnison and a tunnel would need to be dug through 5.8 miles of mountains to bring it to the Uncomaphgre Valley (Pratt, 2010; Smith, 2003). Local municipalities and farmers didn't have the resources for such a project so they appealed to the state of Colorado who began work in 1901, but ran out of funds after digging 900 feet of tunnel (McDonald \& Cech, 2012). The federal government eventually brought their resources to the problem with the passage of the Reclamation Act in 1902. The building of the Uncompahgre Project became one of the first five projects taken on by the new Reclamation Bureau and was the beginning of a long relationship between the Gunnison Basin and Reclamation that continues to this day (Sibley, 2013). Figure 5 shows the Gunnison River Basin and the many reservoirs built over the past century by the Bureau of Reclamation. The Crystal, Marrow Point, and Blue Mesa reservoirs make up the Aspinall Unit and are managed by the Bureau. Current reservoir levels and historical data on inflow, water level, and outflow are available through the Bureau's website. 


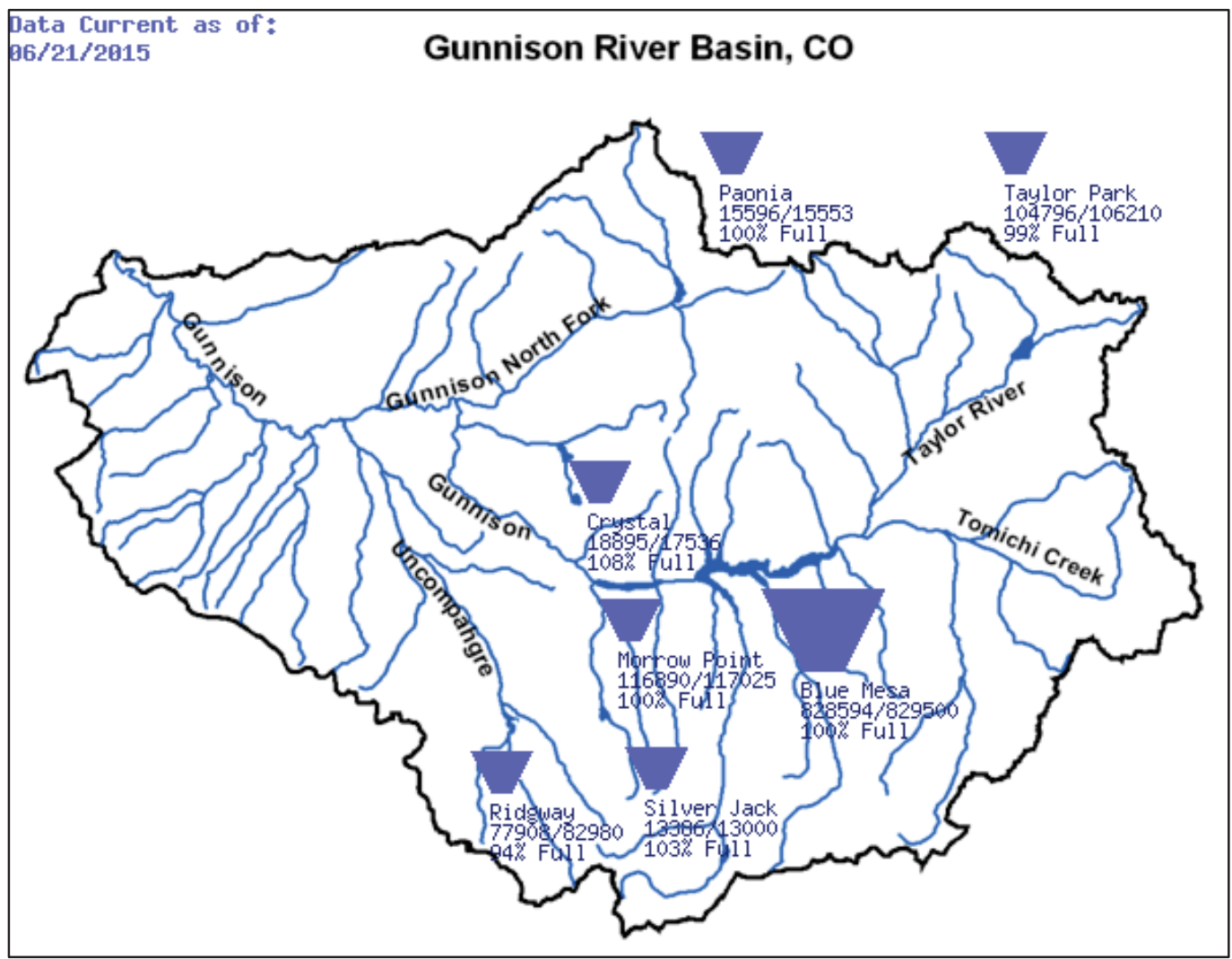

Figure 4: Teacup diagram showing reservoir levels in the Gunnison Basin (February 22, 2015). U.S. Bureau of Reclamation (http://www.usbr.gov/uc/water/basin/tc_gr.html).

The Uncompahgre Project includes 128 miles of canals, 438 miles of laterals, 216 miles of drains and the Taylor Reservoir (Pratt, 2010). Drawing water from the Taylor Reservoir north of the City of Gunnison, it brings water through the Gunnison Tunnel to the South Canal east of Montrose and uses the waters of the Gunnison River and Uncomaphgre River to irrigate over 66,000 acres in Delta, Gunnison, and Montrose Counties (McDonald \& Cech, 2012). Once construction was completed by Reclamation, management of the Uncompahgre Project and payment for construction was passed on to the Uncompahgre Valley Water Users Association who continues to manage it to this day (Pratt, 2010). Figure 6 shows the Black Canyon of the Gunnison, cut over millions of years by the Gunnison River, steep, narrow and deep, some portions of the canyon only receive 33 minutes of sunlight a day. At the bottom of the canyon, downstream from Crystal Dam the Gunnison Diversion dam feeds water into the Gunnison Tunnel. 


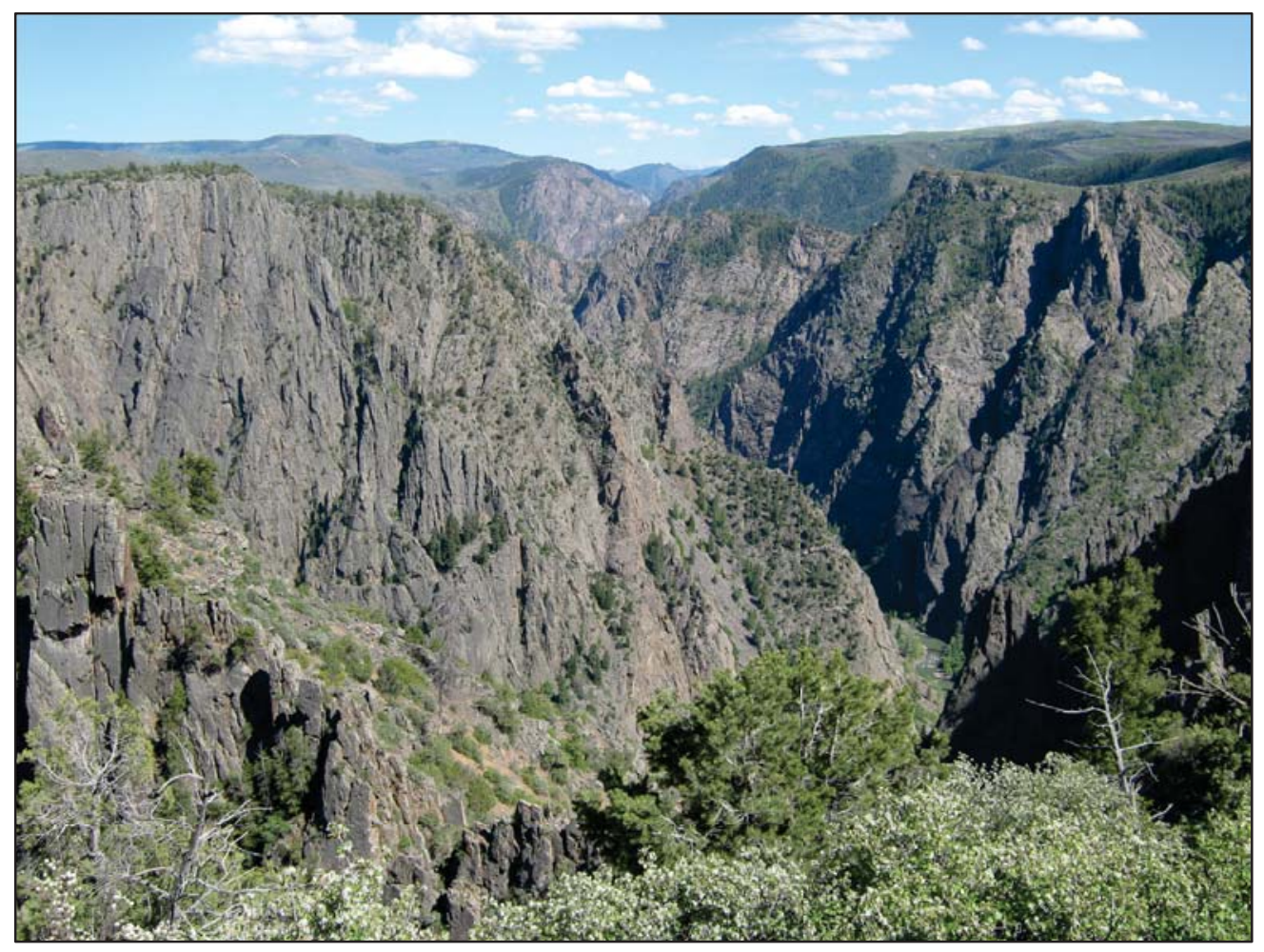

Figure 5: Black Canyon of the Gunnison. Photo: Rhianna Williams 2013.

Later when the Upper Colorado River Basin Storage Project was passed by Congress the Bureau began another project in the Gunnison Basin. This one, called the Aspinall Unit, is run in conjunction with Glen Canyon Dam in Nevada and contains three dams and created Blue Mesa, the largest body of water in Colorado (Hundley, 1975; Sibley, 2013). The Aspinall Unit is operated by the Bureau, while there are workers on site; the unit is run out of the Bureau's Grand Junction office. The reservoir is operated according to the Department of Interior's Record of Decision as well as applicable federal laws (Bureau of Reclamation, 2015).

Smaller storage reservoirs were built to support irrigation through the midcentury. The Paonia Reservoir in the north east portion of the basin is operated by the North Fork Water Conservancy District, the Silverjack Reservoir is operated by the Bostwick Park Water Conservancy District, and the Ridgway Reservoir is operated by Tri-County Water Conservancy District (Bureau of Reclamation, 2015). Reservoir operations are monitored by the Bureau of Reclamation for compliance with management agreements as well as by the State Engineer's office, and the local water 
Commissioner from the Water Court to ensure compliance with state law (Bureau of Reclamation, 2015; Grantham, 2011; Hobbs, 2004).

The Uncompahgre Valley saw the introduction of a new water authority in 1973. During that summer the City of Montrose and the Tri-County Water conservancy district experience water shortages due to the technology constraints at the water treatment plant. The plant could not process enough water to supply the area during peak demand. At the same time the passage of the Safe Drinking Water Act required other municipalities to update their treatment facilities. Three water districts, TriCounty, Menoken, and Chipeta together with three municipalities, the City of Delta, Town of Olathe, and City of Montose came together to form the Project 7 Water Authority. Project 7 treats the water owned by these entities in order to provide potable water to rural and municipal residents of the Uncompahgre Valley.

The seventh entity in Project 7 is the Uncompahgre Valley Water Users Association. The UVWUA supplies raw water from the Gunnison Tunnel to Project 7 for treatment. In exchange, the UVWUA receives water out of the Ridgway Reservoir for their irrigation projects. This exchange, gallon for gallon through cooperative agreements, works to the advantage of each entity making it easier to get the water to where water rights holders want it to be.

The Project 7 system and the agreements between municipalities, water districts and water associations are just one example of how water is handled in the basin. Annual agreements are also worked out ahead of the water year, which begins April $15^{\text {th }}$ as dictated by law, in order to avoid calls on the river and the legal hassles involved.

This basin is facing future water supply challenges in the way of population growth, climate change, and variable hydrology. All of which combine to make managing this developed resource crucial to continued prosperity in the region. As this natural resource is being taxed to the limit, scientists predict demand will outpace supply by 2050. Previously documented levels of guaranteed water has been brought into question as tree ring analysis demonstrates the hydrological variability of the region over 1,200 years (Bureau of Reclamation, December 2012; Woodhouse et al., 2010). The 
likelihood of prolonged and repeated drought is increased through climate change (Bureau of Reclamation, December 2012; MacDonald \& Turner, 2010). In addition, the annual cycle of snowmelt and accumulation that the reservoirs were designed to take advantage of is being altered through the phenomenon of "dust on snow", where runoff occurs earlier in the season and reservoirs are incapable of storing the excess (Painter et al., 2010).

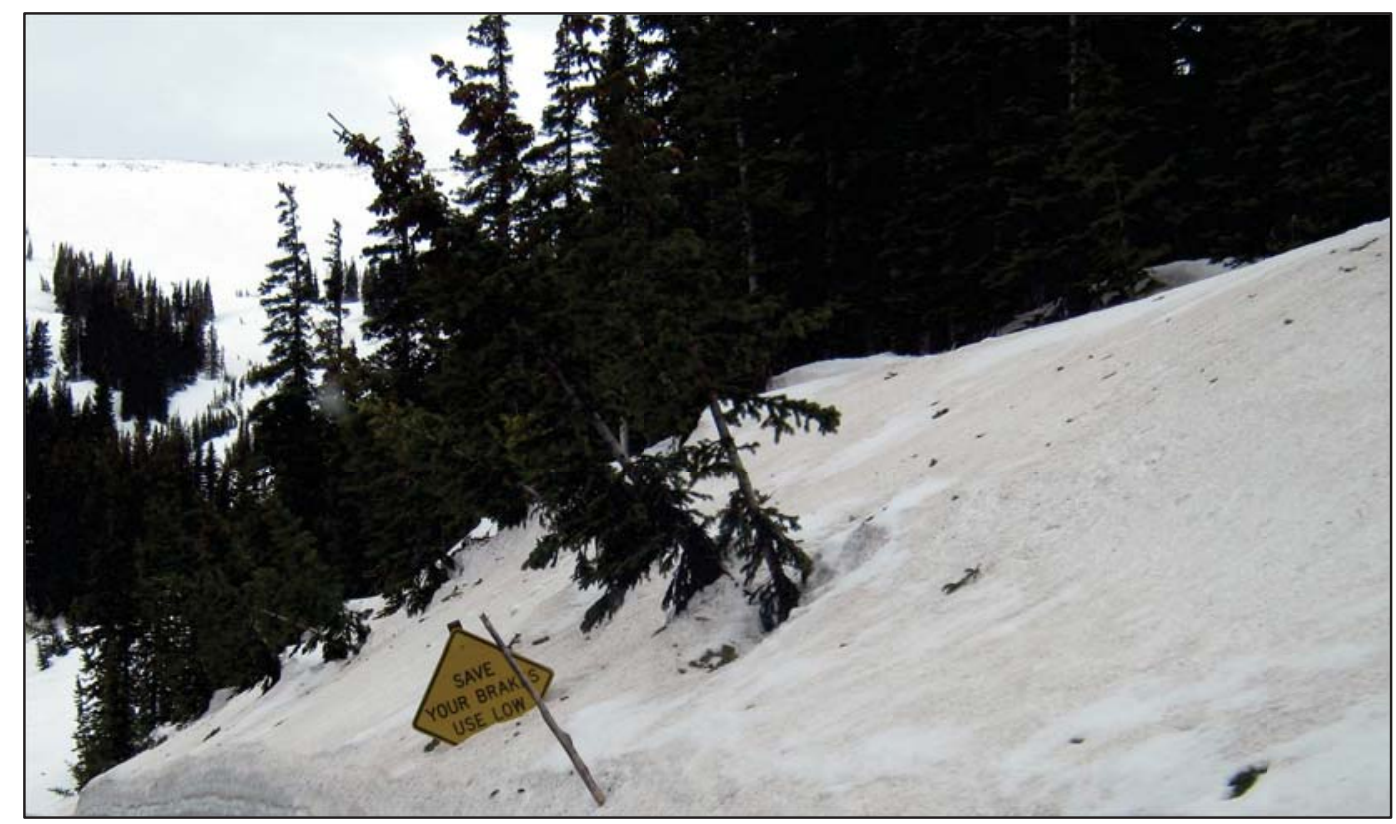

Figure 6: Dust on Snow near Coal Mountain Pass. (2013) Photo: R. Williams.

\subsection{Climate Change in the Colorado River Basin}

The hydrology of the Colorado River Basin is so variable year to year that a long term drought may not signal to people that climate change is occurring. Using historical tree ring data, researchers have charted the hydrology of the basin going back 1,200 years and found that sixty year drought has occurred at least once in that time (Woodhouse et al., 2010).

Climate change is visible however in the annual hydrological cycle. The climate phenomenon of "Dust on Snow" has altered the effectiveness of area dams (Painter et al., 2010). The high mountain ranges of the Rocky Mountains are the areas "natural reservoirs", historically snowpack has stored water annually until mid-June (Painter et al., 2010). In the Gunnison basin peak runoff used to occur around June $15^{\text {th }}$ each year. In 
recent years dust on snow sped up snowmelt on the mountain, shifting peak spring runoff to May instead of June (Painter et al., 2010). Dams which were built on an annual cycle of filling and draining in anticipation of collecting spring runoff do not have room to store the run off if it arrives earlier in the year. Figure 7 shows dust on snow at Coal Bank Pass in the San Juan Mountains at approximately 10,600 feet. The dust, which is blown in from dry conditions in Arizona, speeds up the run off process by decreasing the albedo of the snow (R. Williams, field notes, 2014). However, Dust on Snow is only one piece of how climate change is altering the regions hydrological cycle.

Water resources vary greatly from year to year and drought is common in this desert region. However, temperature changes from climate change will increase the frequency and duration of drought straining an already stressed natural resource. 


\section{Literature Review}

\subsection{Colorado River Basin Water Management}

Existing research on water policy has centered on the benefits of water banks, or the disruption they may make to the existing Water Law system, debating if the current legal structure is flexible enough to accommodate the changing needs of the basin (Karkkainen, 2008; Powell Consortium, 1995; Shupe, Weatherford, \& Checchio, 1989). Researchers focusing on the bureaucracies and laws already in place have questioned if the existing infrastructure provides enough flexibility for water managers (Rajagopalan et al., 2009; Udall, 2014). As a developed resource, researchers question if the existing infrastructure of reservoirs and canals built for irrigation purposes can be repurposed to accommodate the demands of a growing urban population (Gober, Kirkwood, \& MacDonald, 2010; MacDonald \& Turner, 2010).

Another cohort of Colorado Basin researchers have focused on end user public policies and their ability successfully manage water demands (Davis, 2001; Wolfe \& Brooks, 2003). These researchers are divided over whether to focus on agriculture use or domestic use (Carter, Kreutzwiser, \& de Loë, 2005; Larson, Gustafson, \& Hirt, 2009). Many water projects were initially built in the Colorado Basin to irrigate land for agriculture; approximately $80 \%$ of the water used in the Colorado River Basin continues to be used for agriculture (MacDonald \& Turner, 2010). As a result, many studies focus on managing water use through projects aimed at reducing agricultural use (Kanzer, November 17, 2013). Other researchers focus on water exported from the Colorado River Bain for municipal use in metropolitan areas such as Phoenix, Los Angeles, and Denver. Researchers have also focused on reductions through policy changes to alter water infrastructure management and land use regulations governing lawns in metropolitan areas (Gober et al., 2010; Kuhn, 2012; Larson et al., 2009; Sabo et al., 2010).

In the discussion of how to accommodate growth and water use in a water scarce environment, there is a lot of focus on how to change the current system. These studies use their own interpretation of existing data on area hydrology to draw conclusions on 
how to best alter the current system to curb future demand. Currently, there is little understanding of how managers already working in the system are using data to manage the system and how they may be using that data to respond to changes in water availability, threats of water curtailment due to calls from Lower Basin states, or changes to water availability within their own area. In particular, prior research has not considered the social contexts that structure how data is utilized. This research looks to fill that gap by drawing on organizational theory to understand how managers are influenced by the organizational task environment to use existing data resources.

\subsection{Environmental Policy and Data}

Policy makers and resource managers have used data for over a century to set regulations for sustainable natural resource management (Merchant, 2002). Conservationists since the time of Pinchot and Hayes have championed the use of scientific data as the primary means of determining whether resources are being managed sustainably (Hays, 1959; Merchant, 2002; Pinchot, 1910). According to early conservationists, scientifically based management would ensure that current use does not compromise future needs (Hays, 1959; Pinchot, 1910). Over time, policy makers and managers have used scientific data in the policy process to create a complex web of policies and related social institutions to manage natural resource exploitation (Vig \& Kraft, 2010). One the one hand, data is at the heart of this layered system. Scientific testing is used to define what safe levels of toxins are in our environment and collected data on animal populations, weather patterns and flow are used for management of our natural resources (Clark, 1998; Udovyk \& Gilek, 2013). However, this same system may become an impediment to change; even when the data calls for significant adaptation in order to maintain sustainability. This research investigates how scientific data affects water management in the context of water scarcity using a case study of the Gunnison River Basin in Colorado.

In developing sustainable yield management for national forests and water conservation practices in the American West, conservationists like Gifford Pinchot and Samuel P. Hays advocated the use of scientific data to create regulations for natural resource management (Hays, 1959; Pinchot, 1910). The conservation movement was 
based in science and technology, and it was argued that scientists, not politicians, should determine rules for resource management since it was wholly a technical matter (Hays, 1959; Merchant, 2002). It was also at this time that rational bureaucracies, including the Bureau of Reclamation in 1902 and the U.S. Forest Service in 1905, were formed to manage natural resources (Merchant, 2002).

The Bureau of Reclamation was authorized to study and develop irrigation projects in the West (Merchant, 2002; Reisner, 1986). Originally focusing on assisting the development of farmland and settlement in the arid West through the construction of irrigation projects like the Uncompahgre Project in the Gunnison Basin. The desire to build economically sustainable irrigated agriculture was eventually over ruled by a combination of Reclamation engineers' desire to build ever larger and more spectacular dams, favorable federal economic policies, and an optimistic public. This combination promoted the rapid expansion of prairies into farmland during the 1920's, which ultimately resulted into the Dust Bowl of the 1930's (Merchant, 2002; Reisner, 1986). During this time, rational decision making based on scientific data was negated by broader social values.

Later when the Clean Air Act, Clean Water Act, and Endangered Species Act were passed in the 1960's and 70's, lawmakers used scientific research to set environmental standards for industry pollution and resource management (Houck, 2003; Vig \& Kraft, 2010). Acceptable amounts toxic substances in the environment as well as what constituted clean air and water were determined by scientific research (Houck, 2003; Vig \& Kraft, 2010). Scientific data became the basis for setting acceptable levels of pollution, for techniques to clean up existing pollution, and to alert society to new environment dangers. Environmental regulation's authority was based on science's ability to produce rational and factual data (Greer \& Steinzor, 2002; Houck, 2003; Ludwig, Hilborn, \& Walters, 1993; Wynne, 1992).

This time, direct challenges to regulations by industry highlighted the differences between the social norms of scientists and policy makers (Bonds, 2011; D. Michaels \& Monforton, 2005; Mooney, 2004). The norms of policy makers who value certainty were challenged by scientists' acceptance of uncertainty and changing data as a normal part of 
the research process (Abe, Pierce, Loverich Jr., \& Tsurutani, 1987; Bradeshaw \& Borchers, 2000; Ley, 2014). Research on the information flow between members of these two professions have found differences in the social norms of scientist and policy makers which create communication barriers impeding the integration of data into policy (Cash et al., November 2002; Flannery \& May, 2000; Wynne, 1992). These barriers, which may arise from differences in profession, geography, and culture, influence how data is perceived and what data is viewed as reliable or trustworthy (Abe et al., 1987; Bradeshaw \& Borchers, 2000; Cash et al., November 2002).

Despite previous problems with the conservation movement of the turn of the $20^{\text {th }}$ century as well as issues with the command and control regulations of the 1960 's, natural resources continue to be managed by bureaucracies at the state and federal level (Vig \& Kraft, 2010). However there are several problems with a strictly bureaucratic approach to natural resource management. Political scientists have found that the ridged, authoritative structure of many bureaucracies are not suited to manage the inherently variable qualities of natural resources and communities which rely on them (Acheson, 2006; Ostrom, Burger, Field, Norgaard, \& Policansky, 1999). This is attributed to the people who work in bureaucracies and whose success depends on their ability to adapt to norms valued by the organization. These norms typically emphasize following established rules as well as the recognition of role limitations (Acheson, 2006; Merton, 1950). Adoption of these norms causes the original goals of the organization to be replaced by over ridged rule adherence leading to the reduced efficiency colloquially referred to as "red tape" (Damanpour, 1991; Merton, 1950).

In addition, bureaucracies move slowly to change and when they do, the rarely make fundamental changes to policy (Lindblom, 1959; Lindquist, 1988). Researchers find that most policy makers prefer instead to make incremental decisions which are easier to gain agreement upon (Lindblom, 1959; Lindquist, 1988). In terms of this project, the water resources of the Colorado River Basin, including the Gunnison Basin, have been allocated through agreements and laws made by lawyers and politicians, which over time have created a bureaucratic structure of resource management. Within that structure, however, the managers who care for the resource are typically engineering 
specialists with a background in water engineering. Does this difference in who writes policy and who performs policy influence how data is viewed and utilized in resource management?

\subsection{Organizations and Behavior}

Organizations dominate the landscape of modern society, existing in the form of corporations, government agencies, non-profits, and schools. The organization has become the go-to social structure for groups of individuals who are working for a common goal (Scott, 2003). The social structure, environment, technology, and goals of an organization combine to influence the behavior of organizational participants (Cohen \& Bacdayan, 1994). Conversely, organizational participants, the larger environment, available technology, and organizational goals also shape organizational behavior (Scott, 2003). How do these forces shape data use?

Within the literature there are those researchers that focus on how organizational routines and environments proscribe information collection and use. Other researchers focus on the individual choices of people within organizations and how values and education predict information use. Early administration theorists like Weber, Taylor, and Fayol studied bureaucracies and manufacturing organizations (Scott, 2003; Simon, 1978; Weber, 1968). These theorists stressed that the formalization of an organization, assigned job positions, and work descriptions, are an organization's defining feature (Merton, 1950; Scott, 2003; Simon, 1978). Taylor and Fayol believed that maximum efficiency and minimal conflict could be achieved between management and employees by proscribing exactly how long a job should take and how it should be done (Scott, 2003). Weber, who wrote about organizations' specialized administrative staff, or bureaucracy, believed that the bureaucracy was better at achieving goals with great

precision and speed than any other organizational form of his time (Weber, 1969).

However, it was also Weber who first observed the social effects of standardization on people. He described a bureaucracy as an "iron cage," which controlled the behavior of its workers (DiMaggio \& Powell, 1983). Theorists like Weber and Merton were some of the first to recognize that individual attitudes and behaviors 
within the organization are influenced by organizational rewards and penalties associated with performance (Merton, 1950; Weber, 1968; Wellstead, 2011). Merton went further, and found successful individuals in a bureaucracy focused efforts on following bureaucratic rules rather than working toward organizational goals since these were the behaviors rewarded by the organization (Merton, 1950).

In theory, a bureaucracy works to accomplish its goals through the execution of clearly defined tasks done by people in clearly defined roles, and the elimination of personal relationships and non-rational decision making (Schneider, 2006; Weber, 1968). In this way the bureaucracy is viewed as a rational organization; capable of efficiently accomplishing its goals even if different individuals occupy the same role over time (Merton, 1950; Schneider, 2006; Scott, 2003; Wasim, 2011; Weber, 1968). Tasks handled by the bureaucracy will be dealt without favoritism or bias, and everyone will be treated equality, ensuring tasks are accomplished in the most efficient and rational way possible (Scott, 2003; Weber, 1968).

Researchers argue that since people have a limited ability to consider all of the options for complex decisions and tasks and instead of choosing the best option, choose the option that satisfies the conditions for choice (Choo, 1991; Simon, 1978). Organizations ensure people within the organization work efficiently by limiting the range of actions a person can take when faced with a decision (DiMaggio \& Powell, 1983; Simon, 1978). Organizations proscribe not only task procedures and evaluations, but also what information and data are relevant to achieving organizational goals (Lindquist, 1988). Within the organization routine tasks are formalized through proscribed work procedures, this includes what data and information is used in routine decision making (Lindquist, 1988; Majchrzak, 1986). When making routine decisions, data is used by individuals within the bureaucracy to ensure routine functions occur within normal parameters. If small problems occur data is also used to return functions to normal (Lindquist, 1988). Since information gathering and processing takes energy away from routine tasks, organizations typically try to minimize necessary information processing (Galbraith, 1984; Lindquist, 1988). 
Within the formal structure of the organization is the social structure of the organization which encompasses organizational participants and how they influence organizational behavior (Merton, 1950; O'Reilly, 1982, 1983). Some organizational researchers find that participants within an organization change behavior and preferences based on the rewards and punishments organizations give in response to performance (Merton, 1950; O'Reilly, 1982; Scott, 2003; Weber, 1968). In order to perform well within an organization and use the generalized rules as proscribed by routines, individuals within the organization constantly categorize problems and cases in order to decide which procedure needs to be followed (Merton, 1950). In theory, the ability to follow these rules provides the individual with job security (Merton, 1950; Schneider, 2006; Weber, 1968). Weber and Merton found that in response to these rewards individuals within the organization become more attuned to rule following than organizational goal attainment, leading to a slowdown of organizational functions (Merton, 1950).

Other researchers have focused on how the organizational environment changes organizational use of knowledge and data (Edelman \& Suchman, 1997; Majchrzak, 1986; Merton, 1950; Schneider, 2006). Viewing organizations as open systems that interact with the wider environment through the exchange of capital and information, these researchers examine the task environment of organizations. The task environment is the blurred boundary between an organization and outside environmental factors related to organizational goal achievement (Scott, 2003). The environment outside of the organization is what sets the conditions for goal attainment. In order to achieve organizational goals, the organization must adapt to its outer environment (Scott, 2003; Simon, 1978). Researchers find that managers working in the task environment are altered through their focus on the goal of immediate tasks and participation in information flows external to the organization (Cash et al., November 2002; Jones, 2003). In other words, managers adapt their behavior and actions to successfully navigate the task environment in order to achieve organizational goals (Simon, 1996).

Researchers have theorized that there are elements of the environment that contribute to the makeup of an organizational task environment: environmental stability, 
available resources, and the number of organizations competing for resources (Cash et al., November 2002; Jones, 2003; Rajagopalan et al., 2009). In organizations competing in unstable environments, managers conducted more research and followed less routines. However, in competitive and threatening environments, managers conducted less research and relied heavily on established routines (Damanpour, 1991). Through interaction with other organizations in their environment including regulators and suppliers, organizations will change over time to adapt to their environment (Damanpour, 1991; Pitelis, 2007; Scott, 2003). Examples of organizational change due to regulations include adopting new pollution control technologies due to environmental regulation or non-profits keeping detailed accounting records to maintain their legal status (DiMaggio \& Powell, 1983; Edelman \& Suchman, 1997).

Other researchers have looked at the individuals within an organization to see how education and training effect use of information (Abe, Pierce, Loverich Jr., \& Tsurutani, 1987; Bonds, 2011; Houck, 2003; Jones, 2003; Lindblom, 1959; D. Michaels \& Monforton, 2005; Udovyk \& Gilek, 2013). In the use of information some researchers have found that managers with more experience consult organizational files less than managers with less experience. In contrast to the organization as a mechanism to rationalize and control individual behavior, this research views the individual as having limited capacity and time to evaluate new situations and reacts to queues from the environment rather than constantly referring to documentation (Simon, 1978; Wasim, 2011).

In research of federal employees and policy makers, scientists have found that multiple factors effect information use: education, work experience, and position within the bureaucracy were among the most common factors (Levin, 1991; Majchrzak, 1986; O'Reilly, 1982). In the use of data or other information, policy makers were more likely to use data if it was perceived as relevant, came from a trust worthy source, and was easily accessible (Levin, 1991; Majchrzak, 1986; O'Reilly, 1983). However, like in the routines of a bureaucracy, policy makers available choices in actions and information are constrained by what policies and routines were created prior (Lindblom, 1959; S. Michaels, 2009). 
Throughout the literature there are multiple influences discussed as effecting behavior and how managers interact with information sources and data. Education, professional training, and task environment are all found to have some influence. The following research finds that the legal task environment water managers are required to navigate as they manage this resource alters how data is viewed and used. This change occurs through bureaucratic rules which must be followed at work as well as through interactions with regional water managers and legal systems. 


\section{Research Design and Methods}

Between April 2013 and July 2014, I worked for the Uncompahgre Watershed Partnership and the Gunnison Basin and Grand Valley Selenium Task in the Gunnison Basin as an Office of Surface Mining/AmeriCorps VISTA (Volunteers in Service to America) volunteer. Through this experience I met and worked with a variety of people who were interested in water resources in the Gunnison Basin. I participated in monthly water sampling with local volunteers, partnered with K-12 school teachers to provide educational programs on local watersheds, and worked with state and federal agency workers on restoration projects. During this time I interviewed local water managers and attended meetings in the area in order to better understand the complex system of laws, infrastructure, data collection, and people that comprise the current water management system.

While in the field, it quickly became apparent there were large differences of opinion on the impending crisis of the availability of water and the effects of climate change when comparing area water managers, residents, nonprofits, and researchers. How did this difference in thinking and opinion occur? After watching some presentations created by water managers and water professionals, I began to wonder if there something about how water managers received and processed data that created this difference. These experiences drove me to systematically investigate that question.

While living in the research area for fourteen months qualitative social science methods were used including: participant observation, semi-structured interviews, and document analysis. Using the tenets of grounded theory, data collection and theory development occurred simultaneously during research. Throughout the research process hypotheses were developed as new information was gathered. Ideas about differences in education or migrant status and job requirements. These hypothesis were compared with the collected data, hypothesis that did not match the evidence collected were discarded, hypothesis that were supported by collected data were used to develop a theory grounded in the data (Charmaz, 2006; Corbin \& Strauss, 1990; Strauss \& Corbin, 1994). 
Data collection occurred over a fourteen month time span from April 2013 to June 2014 while I lived and worked in the Gunnison Basin. During that time I observed water managers and policy creation by participating in local meetings, collecting and reading documents on local water policy, organizing water education programs, talking to local leaders, and interviewing local water managers. Due to time constraints on travel, the majority of educational and public programs attended were located in Ouray and Montrose County.

The documents collected included: water planning reports of municipalities and water districts, operation procedures of federal projects, publicly distributed pamphlets related to water, documentation on water law, regional planning reports, white papers and newspaper articles. Documents were deemed relevant if they related directly to regional water systems, planning and issues. The news articles and pamphlets collected provided insight into how water managers wanted water and water related decisions to be perceived by the public, as well as how the public perceived water management decisions.

The meetings attended ranged from local meetings designed to inform the public, formal government meetings of the Board of County Commissioners, regional basin round table meetings, as well as area water conferences. Through attendance of local government meetings, public informational sessions, conferences, and regional groups; water managers participate in a rich cultural environment which involves the sharing and absorbing of multiple ideas, policies, and perspectives. By attending the meetings they attended and participated in I was able to discover the topics water managers presented as most important to colleges, supervisors, and the general public. This participation also allowed me to gain a basic knowledge of topics and issues considered important to the area which informed the development of interview questions. Notes and recordings were taken at each meeting, quotes and data recorded were incorporated into the analysis and final results.

A total of nine water engineers, managers, and a water commissioner, working within the Gunnison River Basin were interviewed to better understand how data is used. The interviews varied in length from thirty minutes to an hour and a half with an 
average of one hour. Participants were provided a consent form and copy of the interview questions prior to the start of the interview. The interview questions consisted of thirteen open ended questions on data use, and water planning, the questions are available for review in appendix A of this paper.

Interviewees were identified using publicly available listings on the internet and contacted via email to set up in person interviews. Of the nine original people asked to interview, one referred me to another person within the organization and two asked to have another person from their organization to be present at the time of the interview. The area's water is handled by a variety of local, state, grassroots, and federal agencies. In order to gain an understanding of the range of views on water in the area individuals from the City of Ouray, Town of Ridgway, City of Gunnison, Tri-County Water District, Uncompahgre Valley Water Users Association, Bureau of Reclamation, Project 7 Water Treatment Plant, and Ouray County Water Commissioner were interviewed. This selection of people then represented a grassroots organization, municipalities, reservoir managers, federal project managers, rural water entities, and cooperative water projects within the region.

Each interview was recorded with the permission of the interviewee, and each interview was transcribed verbatim. The transcripts were analyzed for content and patterns using the programs Hypertranscribe and HyperResearch. The initial codes were determined based on the original research question, phrases were coded according to type of data or knowledge referred to, if it was qualitative or quantitative, where the information originated, and tasks performed. As new topics emerged through the coding process they were added to the coding process and previous documents reevaluated to include the new codes. Codes added during the research process included information on common cultural beliefs, topics of water law and policy, conservation measures, cooperation between entities, and local vs. regional issues. The full list of codes and their definitions are available in the appendix.

Throughout the process of collecting, reading, transcribing, and coding, higher level themes emerged which were used to categorize or group codes. Through this process it was found that codes could be grouped into four themes or categories: Water 
Law and Policy, Interconnectedness, Conservation, and Data/Knowledge. A theory on how these themes interact in the decision making process was developed and tested by referring back to the original data to find if contradictory information existed. When found the theory was reformed until it worked in conjunction with the data. 


\section{Results}

"To thoroughly understand and effectively participate in the water business, one must be at least conversant in a multitude of disciplines. Since that does not happen overnight and usually requires years of practical experience, let's start with the fundamentals: the law, the resource, and the application of engineering principles." -Leonard Rice, 'Engineering Aspects of Water Law'

This section presents case study findings in response to questions about data and water management, organized according to emergent themes in the collected data. Overall, I found that the bureaucracy of Water Law shapes what information is collected, shared and reported in the Gunnison Basin. Data is used to determine areas where conservation may take place, however it is Water Law which determines what type of conservation is appropriate. When partnerships or agreements between entities are formed to manage water resources and formulate policy together, data is used to show where water is being used and what water might be available, however it is Water Law that shapes who works together by defining how water may be transferred.

From the beginning of my residency it was stressed by residents as well as at conferences that climate change was altering the hydrological cycle of the region. The 2011-2012 water cycle had been dry and reminded many residents of the severe drought and the calls on the river necessitated by the severe drought of 2002. Residents pointed to quickly melting snowpack and the changing habitat of local pica, an endangered alpine rodent, as signs of climate change. They remarked how glad they were to see snow on the mountain peaks in April of 2013, since the peaks had been bare just the year before. One resident, drove me past an avalanche chute at 9,000 feet and remarked that the snow used to stay through August, but during the past few years the snow was melted by July.

Attending conferences around the basin and in Estes Park, CO, presenters shared data from the International Climate Change Committee and highlighted the predicted impacts climate change would have on the region. In addition, the results of 
the Colorado River Basin Supply and Demand Study had just been released by the Bureau of Reclamation and were still making headlines in the news, at conferences, and local discussion. The 'demand and supply gap' chart (Figure 1) from the executive summary of the BOR report was making the rounds and was frequently included in presentations on water.

One of the first local meetings attended by the researcher was a panel with representatives from the water providers Uncompahgre Valley Water Users Association and Tri-County Water District, as well as local non-profit Eco-Action Partners. Approximately forty residents from the Town of Ridgway and surrounding areas attended. The representatives from the water providers discussed their operations, water rights and issues facing their area which included: the over allocation of water, transmountain diversions, federal water quality requirements, and maintenance costs. TriCounty fielded questions on water availability and supply, responding that the organization was only using about $25 \%$ of the water allocated to them, so there was plenty of water for future growth. In contrast, the group Eco-Action partners, a local environmental group, was working to reduce local energy and water consumption by $10 \%$ through education and outreach efforts (Water Demands in Ouray County, May, 21, 2013).

The difference in tone and structure of the talks given by Tri-County, UVWUA, and Eco-Action Partners stem from the different organizational goals of the represented groups. As water providers, the daily tasks of managing the infrastructure and administration of a water supply require a different educational background and work routine than practiced by researchers or the general public. Most water managers I spoke to have a background in engineering, another in economics, and many took educational courses on the job. While it was initially thought that this background could be the difference for how data was being interpreted and presented, it became apparent that the common thread is the legal environment regulating water resources. This framework shapes the perception and use of water data and information.

While the Supply and Demand Gap chart (Figure 1) was frequently shown at talks and meetings, the 1922 Compact, water calls, beneficial use, or other water law 
topics were more likely to be discussed. In talks about Colorado Water, the person regularly referred to or quoted on the importance of water is not an engineer, or scientist, but a jurist. Colorado Supreme Court Justice Hobbs and his knowledge of water law seemed to be revered throughout Colorado. There could be no meeting or discussion on the physical movement and uses of water without mention or discussion of water law. It became obvious that water use and water law go hand in glove in Colorado, not just for the water manager, but any water rights holder, Colorado resident or reclamation effort. For that reason, as well as information collected during the interviews, Water Law was a critical and overarching theme that emerged as I analyzed the data.

Conservation was another key theme to emerge from the research. As discussed in the background, the attitude toward water use in the American Southwest has changed over time. Originally, the prevailing water ethic of American settlers was that all water must be used to extinction, any water that made it to the ocean was wasted (Reisner, 1986). While that is no longer true, some pockets of the old guard remain. For example I was told of one gentleman in Ridgway who would check his meter at the end of the month; if his use was below his monthly quota he would run the water on his lawn until it was used (R. Williams, field notes, July 20, 2013). In contrast, water conservation is frequently advocated by non-profit groups and water saving irrigation practices is promoted by local water districts.

However, for water managers who have little control over the water habits of the average domestic water user, conservation typically refers to a reduction of water loss within the system. Through regular maintenance to prevent pipe leaks and breaks, or infrastructure upgrades like the UVWUA's lining of canals to prevent water seepage. Conservation also conflicts with prevailing water law, as a reduction in water use could result in a loss of water right. Conservation is also a hot topic in relation to transmountain diversions. The Western Slope works to ensure that the Front Range is doing all it can to conserve water and use what water they do get from the Western Slope to extinction before another diversion is considered (Harmon, May 4, 2014). 
The interconnectedness of the region and its water users also became more apparent over time and the third theme to emerge. Initially focusing on the county of Ouray, I found that the City of Ouray and the Town of Ridgway maintain their own sources of water. Rural residents in housing associations may form a water users group while other rural residents pump or haul their own water, or have water taps serviced by Tri-County Water District who manages the Ridgway Reservoir within Ouray County but partners with multiple water entities across the basin to deliver potable water to their customers. The need to expand the research to encompass the area's entire water system quickly became apparent as I discovered the complex system of agreements and infrastructure which is used to get water to rural residents.

Many residents and government officials recommend that I talk to someone with the UVWUA to understand the history of water in the area. Later, I realized what was common knowledge, Tri-County and the UVWUA entered into regular agreements to supply potable water to the area. In addition Project 7, which treated water for domestic use, treated water for Tri-County as well as five other municipalities and districts down valley. Water for Project 7 and by extension Tri-County actually comes from the Gunnison River and Blue Mesa, the water in the Ridgway Reservoir is used for irrigation.

I came to further understand the complex and interrelated nature of water in the area when Governor Hickenlooper asked the states seven Basin Roundtables to develop and submit Basin Implementation Plans to be incorporated in the state plan (Colorado Governor, May 14, 2013). Not only did these water managers regularly work together to manage water resources through cooperative agreements, they also met regularly to develop policy, and discuss water resources. The interconnectedness of the area is important to the functionality of the area's water systems in a way that involves more people than is usually tapped to manage other resources like forests, roads, or schools.

Finally water data, the basis of my original inquiry, was always present. Data on water flow and snow pack are regularly collected by federal, state, and local agencies and published online. Local radio shows have daily segments announcing river flow in the spring, and snowpack and avalanche conditions in the winter, just like the weather forecast is reported daily in any other part of the United States (R. Williams, field notes, 
April 12, 2014). Schoolchildren and community volunteers collect monthly water samples from local streams to record heavy metal content and $\mathrm{pH}$ data which is made available online and used by policy makers to set regional policy. Water data is everywhere, and freely available, but the perception of what this data means or how this data is used is appears to be different between water managers and others concerned with water use. So, what data is collected and used and why it is used that way is central to how water is managed in this area.

Not only were these four categories (water law, data, interconnectedness, and conservation) repeated throughout my experience of living in the area, were they also supported through interviews and discussions with water managers themselves. The coding completed on the interviews conducted support the categories or water law, conservation, interconnectedness, and data in my research. Figure 8 depicts my theory of how data collection and data reporting is filtered by Water Law and particularly the definition of Beneficial Use and focuses how data is used to make decisions under conservation, and what agreements are made and who is met with under interconnectedness.

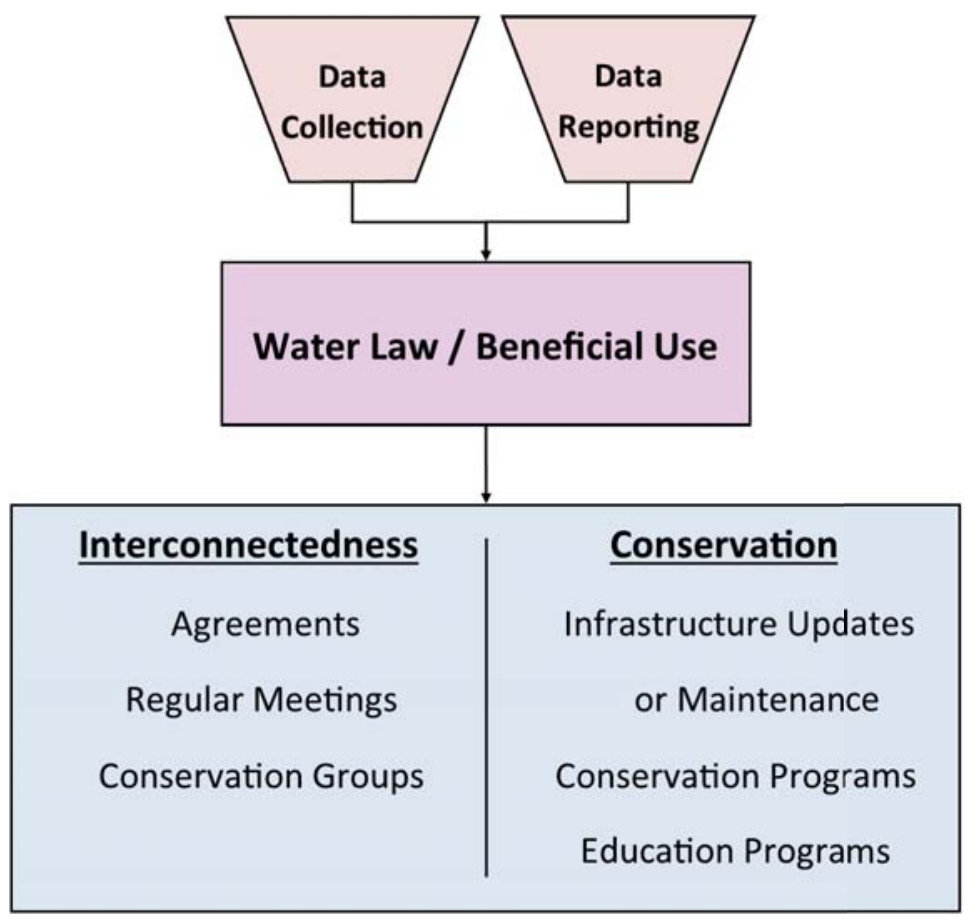

Figure 7: Flow chart of data as it is filtered by beneficial use as defined by water law (R. Williams, 2015). 


\subsection{Water Law}

In the legal system of water the date a water right was assigned and the amount of water from that right used are considered the important data points needed to maintain a right. The amount of water put to benefited use is collected by the water right applicant during the application and approval process. Data on water use by the water right holder is continually collected and filed annually with the local Water Commissioner in order to maintain access to the water right. The culture of water law is pervasive in any discussion of water resources and the fact that the law frames discussion of a heavily regulated resource is not surprising.

What is surprising is the reliance on the legally stated amount of water decreed to a rights holder when talking about future planning and making sure those rights are legally secure. When asking water managers if there is enough water for their users, most refer to the amounts stated in their legal water right. Roger the Public Works Director, for the City of Ouray, "I believe so, with the water rights in the Weehawken Spring and Weehawken Creek I think we're okay,” (Roger, interview, May 7, 2014) This sentiment was echoed by Sal, City of Gunnison, "that's the mentality of our Colorado Water Law, you know first come first serve... We have set ourselves up pretty darn good, from our forefathers, getting in line saying 'We're going to secure these rights' (Sal, interview, June 2, 2014). Ensuring municipalities and water districts have continued access to water rights requires regular data collection, documentation, and vigilance on the part of the water manager.

The City Manager of Gunnison, Sal, recalled one of his first tasks as Water Superintendent, "they [City Council] asked me to find a firm to work with, to get ourselves situated from a water rights perspective. We contracted with an engineering firm, water engineer and the law firm I mentioned, back then and been working on ensuring that we have a solid portfolio in place," (Sal, interview, June 2, 2014). In 2013, the City of Ouray and the Town of Ridgway petitioned the Water Court to prove they should have earlier dates assigned to their water rights in order to secure access to 
decreed water in times of drought. While the City of Ouray was recently granted older rights, the Town of Ridgway's effort was rejected. The Public Works Director of Ridgway, Susann, said, "I think we're going to appeal, I think they missed something," (Susann, interview, March 25, 2014).

While I initially thought drought would worry water managers, it seems that in this area the threat of a call on the Upper Basin by the Lower Basin (particularly California) for water or the prospect of another transmountain diversion is considered the more immediate threat to maintaining water resources. In a presentation to the Town of Ridgway, Dale of Tri-County let the audience know that his organization had applied for a $3^{\text {rd }}$ Fill Water Right for the Ridgway Reservoir in 2010 in order to protect, "against future downstream needs," (Water Demands in Ouray Count, May 21, 2013). This was put more bluntly when the Project 7 manager Gabe, was asked about water needs in the basin. He first referred to water rights, “... traditionally we're going to use 10,000 acre-feet just about every year. We have 18,000 acre feet that's already owned by these entities." But he also opined on what the "real deal" is for water concerns in the basin, "So, we're caught between a proverbial rock and hard place. Where we'd love to send Denver more water to help them, because it's the neighborly thing to do but, nobody's easing off the gas in California either. So, it's not totally on our backs to keep Lake Powell healthy, but we're all going to suffer big consequences if that totally goes south," (Gabe, interview, May 8, 2014).

The perception that water of the Western Slope is a hot commodity which people in the Lower Basin and the Front Range would love to tap is not a flight of fancy. Beginning with Colorado Executive Order D2013-005, Governor Hickenlooper of Colorado has kept the members of the seven Colorado Roundtables busy with developing a basin wide water plan. Through this policy directive managers have been oriented to thinking about current and future water use through a political lens. Worry over the potential of a future Lower Basin call has been heightened by the low levels of Lake Mead and Lake Powell which has been publicized in the press (Finnessey, November 7, 2013; Holm, 2013; Jenkins, 2009; Rodebaugh, 2014). Attendees to Gunnison Basin Round Table meetings know that if the levels of Lake Mead drop below 
the outtake pipes to run the hydro plant (Figure 4, pError! Bookmark not defined.) and provide water for Las Vegas, the city will run dry and millions of people and businesses in the Southwest will lose power (Best, 2014). Those two crises would require the Upper Basin deliver more water downriver in times of drought.

In this tightly controlled, but highly competitive environment, the managerial instinct to refer to the rules of water law has a precedent in organizational literature. Figure 9 shows how local municipalities are at the bottom of a complex system of agencies and policy forums on water law. At each policy level (federal, state, basin wide) there are multiple agencies and regulations municipalities and water districts interact with to different degrees to ensure continued access to water rights. Local water managers are at the bottom of the chart, responding to regulations and needs as dictated by higher levels of government while providing feedback through Basin Roundtables and the Colorado Water district. At this position, local water managers use rules and regulations most favorable to them within the system in order to maintain water rights. 


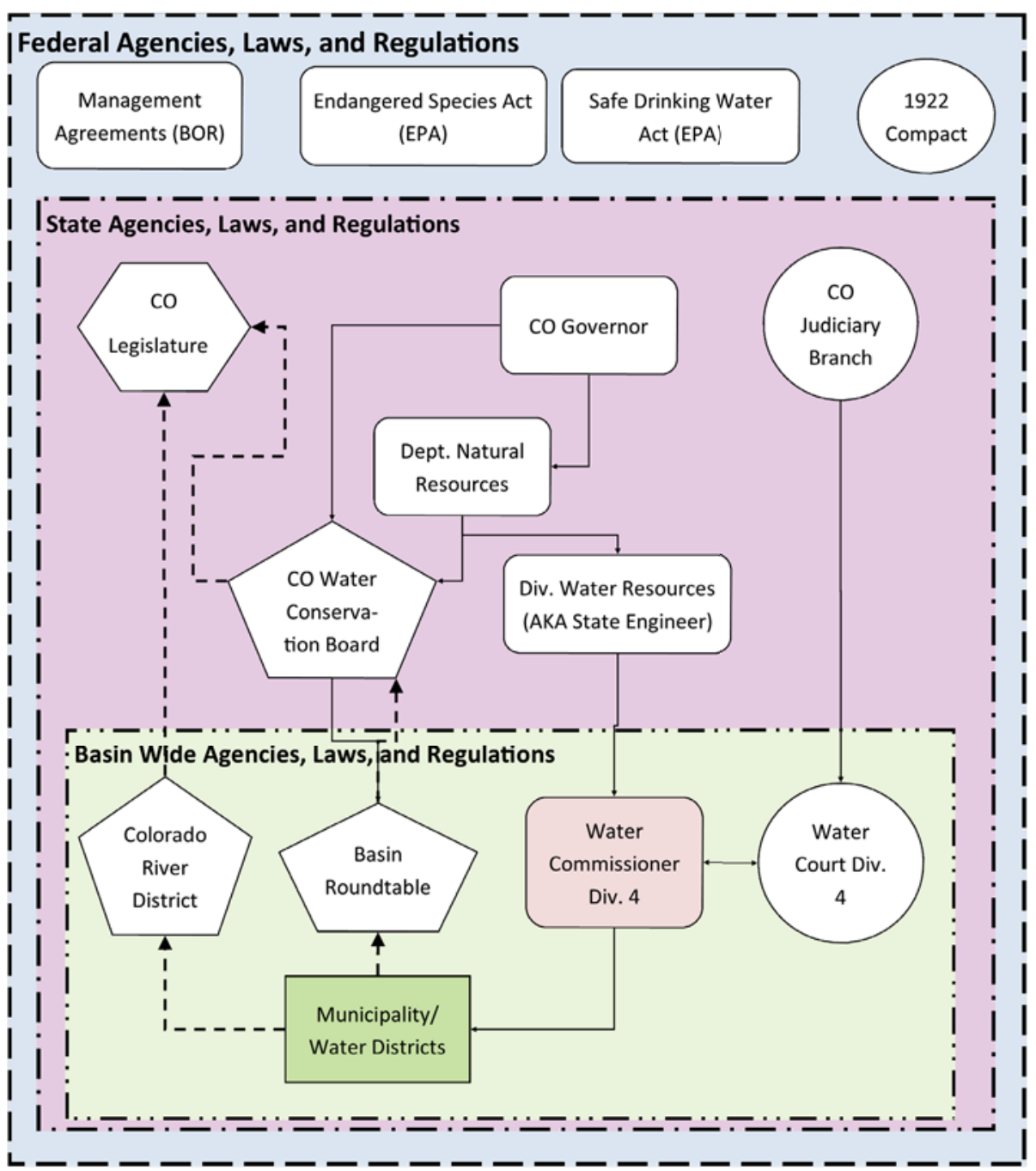

Figure 8: Simplified flow chart of organizations municipalities and water Districts regularly interact with or report water data too. Each entity is nested within a regional, state or federal framework. (R. Williams, 2015). 


\subsection{Data}

"If we underreport our water needs, it looks like there is water here for others."

\section{- Martha Whitmore, Ouray County Lawyer, and County Representative to the Gunnison Basin Roundtable}

While talking to water managers it quickly becomes obvious they have a lot on their plate. There are regular work tasks to attend to, continuing education

, and they attend local and regional meetings; there is a lot going on. However, when I asked if the Water Commissioner collected water data he said, "So that's absolutely what I do, all those measurements that we take, like I say, $90 \%$ of my job is I just measure what's in the ditch. I record that use and at the end of the water year... And that is recorded, and you can look all that up... And that's how all the people, if you're looking up how much land is irrigated, the CWBC puts out that stuff. We go through and sort of say, no, yes, yes, no. And how much water went toward irrigation that comes from my office. That's a big part of my job," (Ryan, interview, March 25, 2014).

So water law is data reliant, but the data has the specific purpose of managing legal water rights. Ryan further explained, "So you're decreed for 20cfs [cubic feet per second] sometime every 10 years, you better be flowing $20 \mathrm{cfs}$ through your ditch. Or you potentially have it abandoned by the state division Engineer, or by private action." Furthermore, data recording and interaction with division engineers is regulated through law, 'You know, a lot of decrees, especially larger ones, put the onus on people to take their own records and supply them to me. I'm not real big on harping on people. If you don't supply it to me, you're running the risk of it being abandoned," (Ryan, interview, March 25, 2014).

A Water Right is not only a way to monitor water; it is also a way to commodify water resources. The annual water use data reported by water right holders is publicly available for others to monitor a neighbor's water use. Water rights which aren't fully used maybe put on an 'abandonment list' for others to claim. In this way enforcement 
of water law and the data collection it requires is not only the arena of the Water Court, but is also enforced by the public.

The need to continually demonstrate full use of a right to ensure continued access by rights holders is recognized by water managers and incorporated into their administrative duties, though it does not take much of their time. Dale estimated that less than 10\% of his time was devoted to maintaining water rights, (Dale, interview, March 11, 2014).

When discussing water management, many water managers acknowledged the need to make sure each water right was being used. In regards to monitoring flows Frank, UVWUA, stated, "Right, now we have to be careful. It could go on an abandonment list if it's not used," (Frank, interview, May 9, 2014) Once on the abandonment list it would be lost to the current holder, and pre-1922 water rights are a valuable commodity to anyone who wants a water right, especially municipalities $(\mathrm{R}$. Williams, field notes, 5/5/14). Regarding the water rights of the small town of Hochtkiss, "they have some flow rights, and some storage rights. And they now have another really senior decree that the Hochtkiss family decided to sell them. So, they've recently acquired some new rights,” (Susann, interview, March 25, 2013).

When talking to a relatively new water manager about the administration of water data he mentioned that he discovered his employer's water use hadn't been reported to the Water Commissioner in two years. Roger then talked about how he knew he had to go have a talk with the Water Commissioner. He said, “That's why I'm going to take an afternoon and go meet with him and say, 'What do you need? What have you had in the past?'" Roger was acknowledging the bureaucratic task of regular use reporting in order to maintain his employer's water rights (Roger, interview May 7, 2014).

However, water managers also collect data to monitor water consumption as well as the structural integrity of system infrastructure. Flow meters are kept on intake and outtake plants and at regular pipe intervals to monitor for leaks and breaks. All water providers but Ouray have meters on homes and businesses, though they may soon be 
required to do so by the state (Staff, 2014). In the cooperative and complex system run by Project 7, the water treatment plant monitors most of the pipes owned by the municipalities as it makes repairs easier. "We kind of take ownership of their water here at Fairview [points to map on table], we run it through our process, we run it through the pipeline to them. And we kind of shepherd it, even there all the way to their customers and we take some of the responsibility for the end user," (Gabe, interview, May 8, 2014). Repeatedly, I was told when the water treatment equipment is working above $80 \%$ capacity, it's time to get a new plant, and so data is used to plan for infrastructure improvement (R. Williams, field notes, March 24, 2014). Organizations utilize outside engineering firms when planning new infrastructure projects (Williams, September 2012; Wright Water Engineers, May 2014).

In this way data is focused on ensuring continued rights to historic amounts of water, daily operations, and maintaining equipment. "Well we read reports from the USGS and other daily reports and the NRCS, SNOTEL sites, we track them pretty heavy, it gives us an idea of what we're looking at. The NOAA, and the Bureau of Reclamation, we keep close tabs on those reports," Frank related. "Gauges you know, we record them every morning, the ones that are key to the project here. And track that and it helps with the daily and just like yesterday... We knew this cold spell was coming in and we could see things were going down pretty fast so we ordered another 100 feet from the Tunnel just to hold. Hold us up," (Frank, interview, May 9, 2014). So, data collection from flow gauges is important to monitoring and maintaining daily operations.

"I'd say we meter, or measure, the water we release. We on a daily basis, determine how much the reservoir rises or falls. We can then tell how much water came into the reservoir and we keep a running tab coming into the reservoir against what we supposedly have available to us... We look at that daily and we do all the mathematical manipulations of the numbers to figure out whether we should increase releases, cut releases, what we should do," (Dale, interview, March 11, 2014). When I asked, after the recorded interview, if I could read the operating procedures for the dam, he told me to read Colorado State Statue 37 (Dale, interview, March 11, 2014). 
Reports and information collected varies from manager to manager, those who work with potable water are members of the American Water Works Association (AWWA) and read their reports. Managers also talk to colleagues or have sources they trust to refer items of interest to them. They would pick and choose what they needed. Sal remarked, "And most of it is online. So, it's not like I'm reading publications constantly... We have this long, solid relationship, with our legal firm. They're job is to look at stuff and say "Hey you better be aware of this one." Then we have the guys in the field who are saying "Hey, we should be doing this... how about that. Think about this one." The information comes from many quarters. And I don't necessarily sit around, coveting my latest issue of the Water Education Magazine or something," (Sal, interview, June 2, 2014). All are aware of the massive 1,500 pages of the Colorado River Basin Supply and Demand study, but have not read it.

Gabe, from Project 7 agreed, "And then the front line stuff, we get reports from Gunnison Basin Round Table. I'd say that's probably where I get a lot of good source data that I know is really reliable, I'm interacting with those people," (Gabe, interview, May 8, 2014). Sal, also mentioned the importance of meeting people, "I went to a webinar; it's maybe been a month now, or less. Where we discuss the Colorado River Compact and the dynamics of that particular relationship and agreement... And wow, what an interesting group of folks. So, I had an opportunity to network and discuss issues." He related it to another meeting he attended when he first became Public Works Director, “....it was very interesting and cordial and collegiate conversation. It was a good time. And I was the young punk at the table and they were quite open. And they were willing to share with me. I just thought it was kinda interesting," (Sal, interview, June 2, 2014). From these conversations and through regularly attending meetings, it is obvious that regular interaction with other water folk is an import source of information for local water managers as well as data collected on their own systems.

From the interviews, I found that data is regularly collected from gauges owned by the organization, as well USGS, and State of Colorado, and used to monitor current activities and equipment needs. Each organization owned gages for its own equipment 
in addition to monitoring a few federal or state gauges for streams or rivers which fed into their own system.

It appears that reports from outside entities as well as regular attendance of meetings and groups inform water managers of what's going on in the water world. It is from these regular meetings, that water manager's use of data would be adapted through working with other people in the water business. This would support the theories of a heuristic learning of law proposed by Acheson (2006). Also, there is evidence that those individuals viewed as more reliable and knowledgeable have their views valued among water managers as proposed by Abe, Bradeshaw and Borchers (1987; 2000).

\subsection{Interconnectedness}

"The real key... all these different agreements, you know. We worked with these guys to come up with these agreements to make this complex system work." -Bo, Interview, May 29, 2014

The nature of water in a water scarce environment and rules governing water allocation has historically lead to conflict and costly lawsuits (Reisner, 1986; Sibley, 2012). Over time, groups have formed to work out their water needs to avoid conflict and ensure a steady flow of water (Sibley, 2012). In discussing how water is supplied to residents and irrigators of the Uncompahgre Valley, three of the managers interviewed helped paint a picture of the water delivery system. It begins with the UVWUA, "Well, we deliver water to about 80,000 acres, or just under that right now, and about 50 to 3,500 customers. So you gotta try to keep the water dispersed evenly throughout the project. We've got several hundred miles of canal and lateral that we operate and maintain. Plus the reservoir up at Taylor Park, that's our reservoir," (Frank, May 9, 2014).

Due to geography, water from Ridgway Reservoir is easier for the UVWUA to deliver to a number of its canals and members south of Montrose; locations which are upstream of the Gunnison Tunnel managed by UVWUA. As described by Gabe of 
Project 7, "or a lot of the water, 99\% of the water, we treat comes through Blue Mesa, Marrow Point, Crystal, through the [Gunnison] tunnel and into our reservoir. A lot of the water rights owned are here in Ridgway Reservoir; 18,000 acre feet here [points at Ridgway Reservoir on map.] The Water Users [UVWUA] are kind of a seventh partner in this system, that trade us gallon for gallon of water here for more water here [points to Gunnison Tunnel and then Ridgway Reservoir] it helps us both. Our water rights are here [points to Ridgway on map] and it would be hard for us to get the water to here [points to Project 7]. And for them [UVWUA] they can use the water out of Ridgway to really water well all this stuff West of the River; which otherwise it has to go down South Canal and go across the syphon and come across over here. So, it's kind of a win-win for everybody," (Gabe, interview, May 8, 2014). Figure 10 shows the basin and traces the path water takes from Taylor Park to the treatment plant over fifty miles away.

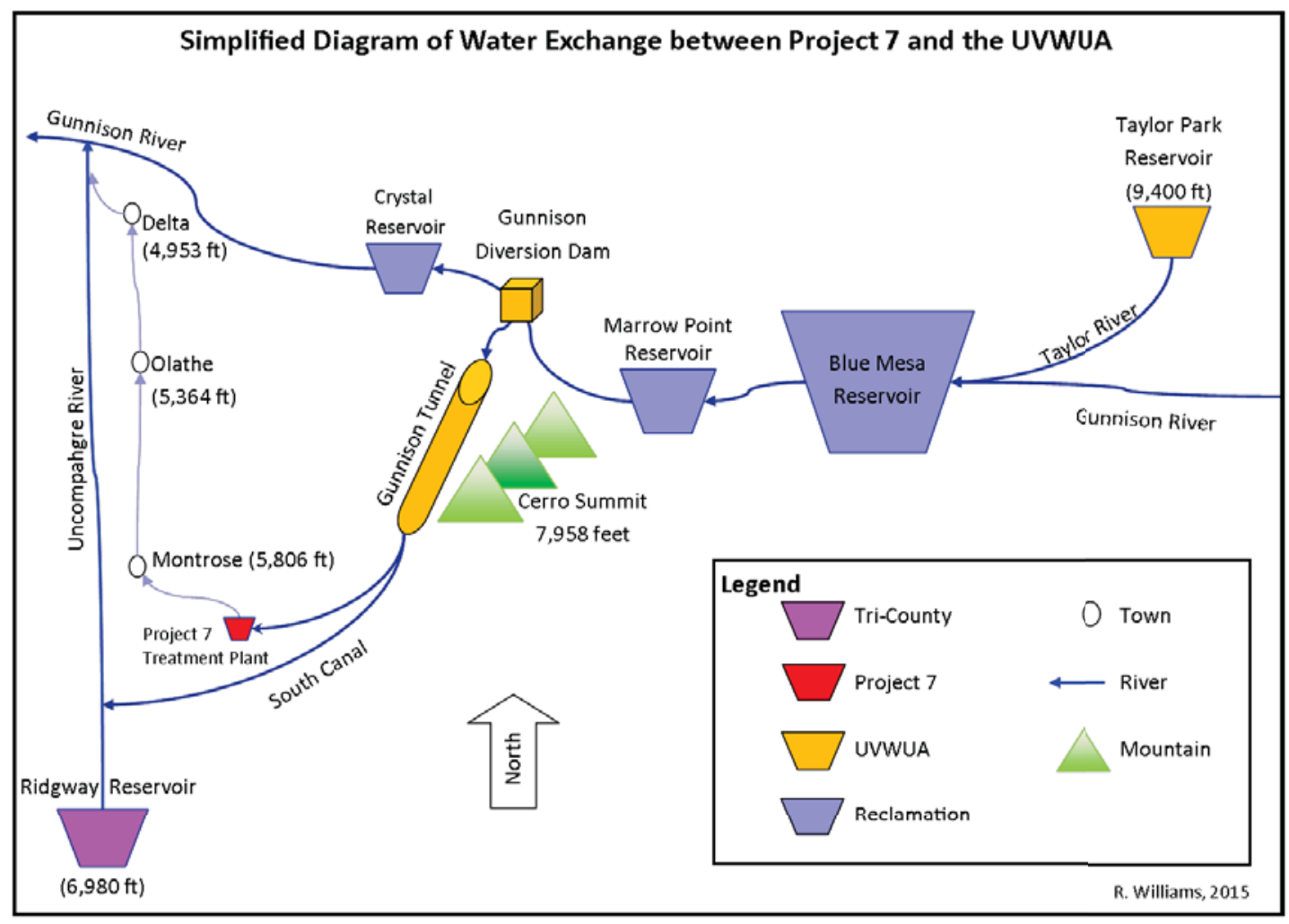

Figure 9: Water from the Taylor Reservoir owned by the UVWUA flows through the Bureaus Aspinal Unit and Gunnison Tunnel where it is exchanged on paper for water out of the Ridgway Reservoir over 30 miles away. 
Water from Taylor Reservoir managed by UVWUA flows through part the Bureau's Aspinall Unit on its way to the Gunnison Tunnel. "So, the exchange that occurs with Tri-County, basically, that water... There's different exchanges going on and everything. So some of it is, you're right, Taylor Park, or... Aspinall water, some is just water used from the water rights we have on the Gunnison. Some are from Taylor Park if you get up in an exchange with Upper Gunnison," (Figure 10) went Bo from the Bureau. "You know, we worked with these guys to come up with these agreements to make this complex system work, utilizing existing projects that are built for them and past other things past once you've figured out how to do them, so yeah... It is a complex system; you hopefully have a good handle on the thing," (Bo, interview, May 29, 2014).

As these systems work together the Water Commissioner also knows what's going on. Ryan relayed the multitude of data he reviewed regularly. "Um, the information I use, there's some exchange water out of Fairview [Reservoir]. So the Gunnison Tunnel brings water in the South Canal, dumps it in the Uncomaphgre River. (Figure 10) They take some water out of that, for Project $7 \ldots$ some of that water is exchanged into Ridgway Reservoir. They get credit for that water coming out," (Ryan, interview, March 25, 2014).

Ryan continued, "So, I go to get information from the Fairview Gauge... I get daily emails of evaporation numbers from Tri-County water that operates the reservoir. Um, I get the actual elevation of the reservoir from the Bureau website. I get release information... I think that's USGS, from below the [Ridgway] Reservoir. So, what we do is, we know how much, we know what the elevation is, we know what is going out, we know how much is evaporating. We back calculate how much is coming in." Out of everyone I interviewed, Ryan seemed to be the most data oriented (Ryan, interview, March 25, 2014).

The complexity of this system requires organizations to meet and work out arrangements for the continued delivery of water and to make new agreements annually using data on projected streamflow based on annually reported snowpack. The meetings and communications water managers must participate in with outside organizations to ensure their organization gets the water it needs is the task environment (Figure 11, p69). 
Referring to a recent agreement in his area, Sal related, "And it's actually, that's last year. We avoided turning on our Gunnison town ditch flows so the Uncompahgre [UVWUA] would not call the Tomichi ditch. And it was probably the first time in history, that it was that kind of agreement," (Sal, interview, June 2, 2014).

These agreements are used to transport water, reduce the numbers of calls on the river, as well as support maintenance costs. Frank described some agreements in the Upper Gunnison, “....it's the Association we're, like the four parties, we have several contracts. Together Taylor Park, Taylor Reservoir has a four parties group that started in 1975 Agreement; which is the Upper Gunnison Water Conservancy. The Bureau of Reclamation, Colorado River District and the Uncompahgre Valley Water Users, and we share some of the expenses on the dam now. They pay us, you know, so much just for up keep. It's not nearly what it costs; we have the majority of that to do," (Frank, interview, May 9, 2015).

Existing and working in the task environment requires managers to learn political skills not otherwise required by engineers. The political skills acquired on the job by these managers is in opposition to the original arguments made by Progressives for why engineers should manage natural resources. Dale, when asked about his degree in Civil Engineering, joked, “...that was a long time ago, I'm technically incompetent at this point because I've been doing this other stuff for so long, I couldn't make my living as an engineer... I'm not a technical guy anymore," (Dale, interview, March 11, 2014).

Through interactions with other water managers, water law authorities, and attending meetings water managers learn skills in addition to the engineering knowledge needed to maintain and secure rights for their organizations. From observations on data reports, at meetings, and personal remarks, these skills include familiarity with the language of water law, and complying with data requirements in order to stay compliant within the law. Through the experience of working in the task environment of managing water and water rights, managers adapt their behavior to include water right data, specifically data and amount appropriated for water planning. Figure 11 conceptualizes how the task environment water managers exist in is a 'between' space of the 
organization that is a more socially porous area than the inner sphere occupied by workers in the 'organizational core' of the environment work in.

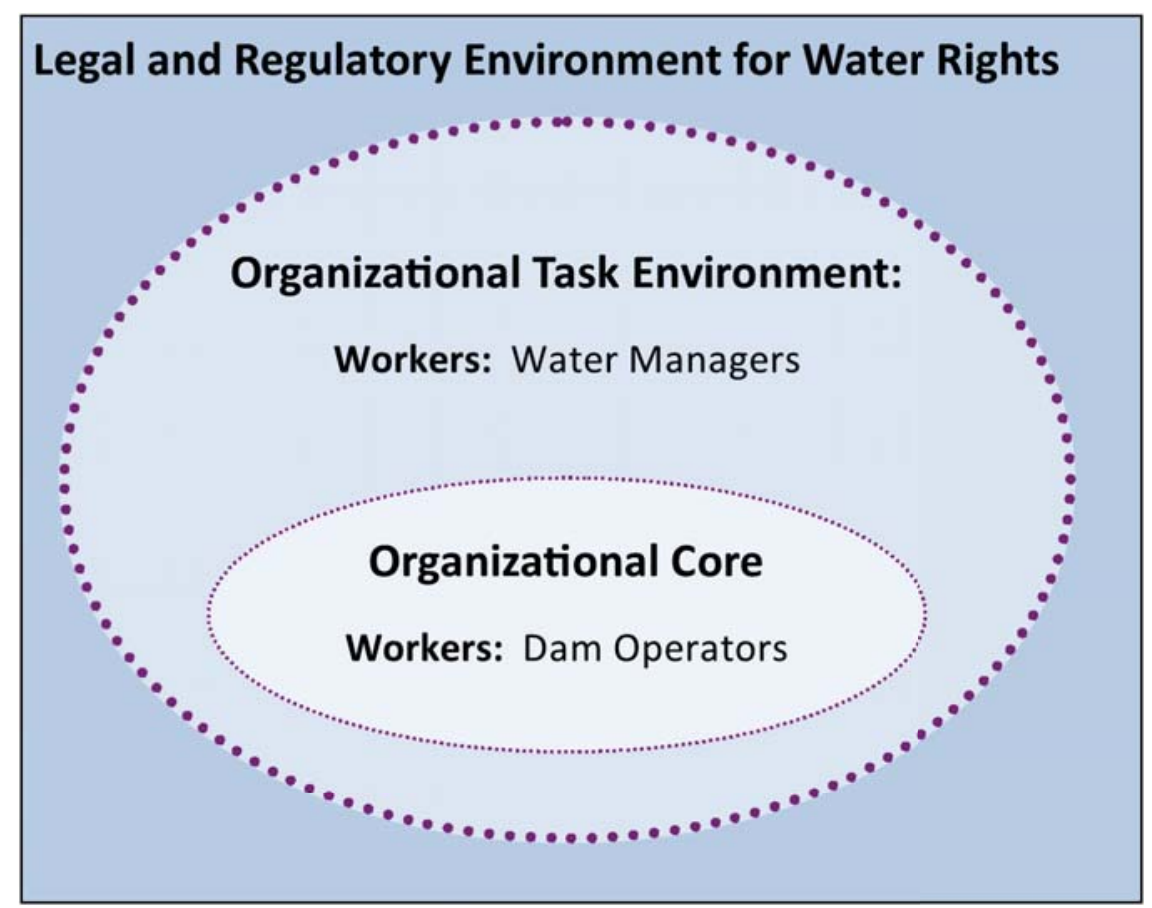

Figure 10: Task Environment of Water Managers. Water Managers exist in an outer, socially porous, sphere of the organization in which they work with many people inside and outside of the organization to ensure continued access to water rights.

\subsection{Conservation}

Of all the water managers I talked to, only one person directly commented on climate change without being asked. We were discussing the "great and growing cities doctrine," which allows municipalities to acquire water rights to use for future growth. Susann commented, "I think in the small towns. The physical supply is going to be the bigger deal as the climate changes," (Susann, interview, March 25 2014). Others, when asked if future climate change was taken into account when planning future use, either didn't think climate change was real, didn't discuss climate change because it was a political issue, or thought they were okay with the water they had allocated.

Conservation is both an ethic and a practice, what conservation actually means depends on who you talk to and what they are trying to conserve. In areas that practice Prior Appropriation, it was historically thought that water flowing into the ocean was 
wasted (Reisner, 1986). In addition, it is argued you cannot conserve water since it cannot be created or destroyed and water returns through the natural water cycle. So, if people don't use the water now, “it'll just flow downstream anyway" (R. Williams, notes). These basic ideas about the nature of water are the basic premise of beneficial use and water law. The County Commissioner described beneficial use of water in Colorado this way, "Because remember, the water all belongs to the people of the State. We want to have that water put to beneficial use..." (Ryan, interview, March 25, 2014).

Currently only the Colorado Water Conservation Board can own in-stream water rights to benefit aquatic species, otherwise flow for the natural environment is not considered a beneficial use. Another peculiarity of Beneficial Use, is residential lawn watering, watering your grass is considered 'irrigation' and thus a beneficial use. An effort to curb law watering at the state level has met stiff resistance from realtors and developers who point to lawn irrigation as a legal beneficial use that also recharges groundwater reserves (R. Williams, field notes). The cultural norm of using water for defined beneficial uses to maintain a water right thus also slows the adoption of some conservation measures. Due to duties, rules, and budget limitations there are limits to what conservation measures Water Managers can implement in instances where they would like to promote a water conservation ethic, particularly among residential communities. Figure 12 shows an irrigation pump used in residential communities to irrigate lawns using ditch water.

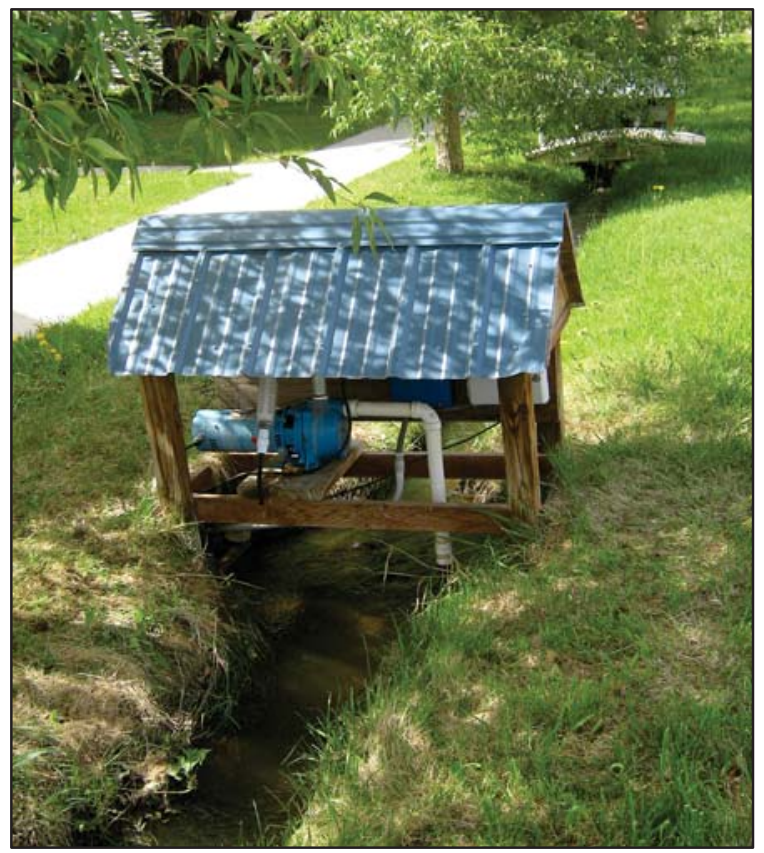

Figure 11: Residential water pump for town ditch in City of Gunnison, CO. Photo: Rhianna Williams 2014.

\section{Ryan related the following}

experience he had trying to get new residents to obey a call on the river, "You, can't 
imagine how problematic it was trying to get people to not use that water. I had an old couple, whose self-esteem was totally wrapped up in how green their grass was, I made them cry. I finally said, 'You get that pump out of there.' They'd irrigate at like ten at night and thought nobody could see. You could see, they're the only green grass there, everybody's was burning up, but theirs was the same [green] color. So it was very apparent what they were doing," (Ryan, interview, March 25, 2014).

Efforts to conserve water are met with some resistance, particularly since unused water may be put on an "abandonment" list in which a water right holder may lose some or all of their water right (Grantham, 2011). As explained by Ryan the Water Commissioner, “...Colorado is a 'Use it or Potentially Loose It' state. So if you're decreed for 20cfs sometime every 10 years you better be flowing $20 \mathrm{cfs}$ through your ditch. Or you potentially have it abandoned by the state division Engineer, or by Private Action," (Ryan, interview, March 25, 2014). Abandonment is a concern of entities holding multiple rights, as water rights holders have to make sure the water rights are being put to beneficial use. Sal described how his city administered water in order to maintain their right, "Well, we now have an accounting type of system for all of our various uses, or rights. And we say 'Hey, we've got to exercise this right on this day...' (Sal, interview, June 2, 2014). In this way Colorado Water Law has inadvertently discouraged water conservation while encouraging all water is put to beneficial use. In addition, since private citizens can apply to have water put on the abandonment list through private action, this social norm is also enforced by the general public.

Of those interviewed, the City of Ouray stood out for not having instituted a drought plan or water saving measures in town. In fact, the City of Ouray did not meter home water usage at the time of this research. In this case, the state of Colorado was stepping in to move the municipality forward. According to an article in the local Watch Newspaper, in 2013 the City of Ouray, "Council unanimously approved a resolution supporting a $\$ 35,000$ water efficiency grant application to the Colorado Water Conservation Board to help pay for the development and implementation of a Water Efficiency Plan. The plan was mandated by the Colorado Division of Water Resources last summer, when Ouray's water supply was called by downstream senior water users." 
Through this action by the state, one of the last holdouts in Colorado to eschew water meters was forced to develop a water conservation plan.

However, fourteen years of drought and the headaches of dealing with calls on the river has started to change policy and minds. Dale's take on changing policy was, “The fourteen years we've just went through has turned people's heads. There are things, ... organizations like mine who are doing things to force conservation on people. They're instigating water rights structures that force conservation. They're educating...,[the] public," (Dale, interview, March 11, 2014).

Frank, from UVWUA, had similar views on conservation, "It's definitely tightened up, you know we've gone through some drought years. You know, you tighten up then. And the irrigation practices are definitely changing... You're forced into it in a drought; you have to keep on top of your water," (Frank, interview, June 9, 2014). This attitude is still not incongruent with water law, as there are exceptions within the law which allow using less than the full amount allotted during a drought.

However, there are a range of views on water use in the area. When I asked, Sal if the City of Gunnison had a drought plan he responded, "Drought? Get a grip on it folks, we live in a dry climate... We've initiated informal water restrictions on a voluntary basis with Western State [University], the school district, and the city parks," (Sal, interview, June 2, 2014). Dale echoes this idea, "So, we have to realize that fact, and you know, we have to change public policy to reflect the fact that we live in a desert. We should have desert-scape,"(Dale, interview, March 11, 2014)

When Water Managers do want to increase conservation by water users they have limited tools to do so. "Back, and this is when I [Sal] was Water Superintendent, we would buy water saver kits. And I'd get a call from our finance department and, "Hey, this person has a high water use, and their bill is for $\$ 100$ this month." ...I'd go look at the meters and make sure it was all proper. Then I'd say, "Hey Customer! Mind if I take a few minutes and do a little survey of your water system here?" I'd go through and check everything. And then I'd bring them to the water meter and I'd say, "Listen to 
your toilet, see how it's running? See how this meter is spinning? That's why your bill is high," (Sal, interview, June 2, 2014).

Dale also related how they used to give Water Saver Kits to school kids until they ran out of funding (Dale, interview, March 11, 2014). He and Frank of UVWUA also give presentations to the public when invited (R. Williams, field notes, May 20, 2013). Susann made room in her busy schedule to give the Ridgway $4^{\text {th }}$ Grade class a tour of the wastewater treatment plant (R. Williams, field notes, March 24, 2014). Ms. Robin of the Ridgway Elementary engaged her class in monthly water sampling and other activities to raise awareness about their watershed until she retired (R. Williams, field notes). Sal related to the struggle to keep ongoing programs in the schools, "The grade school discussions... it depends on the personnel involved, and year to year it changes. And you're always sorry to see one of the good ones leave, 'cause you have to start all over again. But you know, we offer field trips,” (Sal, interview, June 2, 2014).

Some municipalities have plans in place to request residents to restrict use during drought. Susann shared her experience with water restrictions in two of the towns she works for, "The town [of Ridgway] has, a voluntary water conservation plan where we don't let people water outside during the heat of the day. And we restrict on how many days a week we can water... . In Hochtkiss they are incredibly effective to the point where revenue went way down. When we went to restrictions and told people there wasn't enough water they [Hochtkiss] got into a [budget] deficit that season [2002]," (Susann, interview, March 25, 2013). This story also highlights another dilemma of the commodification of water and water providers.

Water providers are selling water to maintain their operations, without supplemental income, conservation would hurt these entities ability to maintain their infrastructure. This also raises another issue with culture, Dale related how difficult it is to balance the books and convince people they need to pay for water. "They think: water comes from the sky, it's free. Why do I have to pay for it?" (Dale, interview, March 11, 2014). 
When it comes to dealing with future drought, Ryan relayed a lesson he was taught in his last year of college. The class was told about a ten year drought in Texas from the 1960's which had left a reservoir almost bone dry. When it started to rain one day, the class was asked, should the dam tender let the water go through, to irrigate dry crops, or try to fill the reservoir? Turns out that rain, in one day, filled the reservoir with some to spare, and ended the ten year drought (Ryan, March 25, 2014). It seemed to me that the moral to the story was, with water, sometimes you just can't plan. Dale echoed this sentiment, "So, if we've got a sort of normal spring, we've got plenty of water this year. If it blows away, evaporates and blows away, to Iowa, or where ever it lands east of us. I've seen it happen; I've seen us lose 50\% of snowpack through April and most of May, it can happen, just from the wind," (Dale, interview, March 11, 2014).

Within the water entities interviewed and studied following the norms of water law were consistent. In the theme of Conservation there is change currently happening on the state policy level as well as variations throughout the basin. The City of Ouray was an outlier in its lack of conservation measures, until it was required by the state to develop a water conservation plan. All other entities had some form of drought plan or conservation measures in place.

Currently, conservation is being pushed by groups interested in environmental preservation and environmental recreation. These groups are active in devising ways to keep water in the stream within the legal framework through water leases or other measures. Other non-profits, such as Eco-Action Partners mentioned earlier, have goals to reduce domestic water use in the region through education campaigns. Local soil conservation districts and the Gunnison Basin and Grand Valley Selenium Task force work with farmers to improve on farm irrigation and line canals to reduce water seepage into the soil. 


\section{Discussion}

These findings extend the current body of research on water management policy by explaining how the organizational task environment shapes water managers use of data in day to day operations. The regulations imposed by outside governing organizations combined with the routine requirements of bureaucratic systems serve to focus limited time and resources into the collection and use of one category of data. Water managers working in the organizational task environment adapt their behavior to comply with the requirements of water law in order to achieve organizational goals $(\mathrm{S}$. Michaels, 2009; Scott, 2003). This adaptation occurs through routine work procedures, as well as social learning from peers and interactions with water law representatives.

In the context of day to day operations and procedures, data collection and use is proscribed through laws, regulations, and bureaucracy. This is consistent with previous research on how bureaucracy and organizational routines shape behavior (Cohen \& Bacdayan, 1994; Damanpour, 1991; Merton, 1950). Available choices are narrowed through proscribed routines and previous decisions to ensure managers work efficiently when faced with a decision (Choo, 1991; Simon, 1978). These decisions and records are created to ensure operations continue as different individuals fulfill the same role.

New decisions continue to be made with input from water managers, lawyers, and the public. In the Gunnison Basin, water managers interact with water law representatives in the form of Water Commissioners and liaisons to the Colorado Water Conservation Board who make monthly reports to the GBRT. The findings from this case study supports prior research on information use by managers and policy makers: managers more readily accept information from trusted sources; in this case sources include other water managers, lawyers and members of the GBRT (Abe et al., 1987; Cash et al., November 2002).

The use of data to secure rights is codified through bureaucratic procedure as well as social norms. The social norm of adhering to water law is promoted within the profession of water management through regular professional meetings, and presentations. This supports previous research identifying social norms as a key 
influence over behavior (Flannery \& May, 2000). In this case, regular data reporting and maintaining access to a senior water right through documentation were important tasks for water managers and regularly discussed at public meetings. Within organizations, water rights are also valued, making it easier for managers to use water rights to discuss water issues and use it for planning.

The interconnection of the legal and physical structure of water makes a common language of water necessary to engage in organizational agreements and meetings. Almost all of the organizations represented in interviews had multiple agreements to manage their water. From leasing water rights to local farmers, to trading water on paper to ensure the delivery of potable water to the valley, this complex system is sustained through cooperation, agreements, and infrastructure. Water right allocations and the data reporting water use is important to this infrastructure in order to manage water calls, leases, and equipment. This system, which exists in the task environment for water managers, supports the need to utilize and use water rights data in planning for future use, even usurping historical hydrological data.

Also seen in previous research are managers tendency to adhere to rules in a hostile and highly competitive resource environment. Area managers are aware of, and frequently reference in casual conversation, who has the most senior rights in the basin and who can call their organization's water rights during drought. An additional fear of water grabs from the Lower Basin as well as the Front Range raises the perception of a hostile water rights environment. Knowing the area has little political clout when dealing with the Front Range or the Lower Basin; managers adhere to the rules which benefit them. This is the case in the Gunnison Basin, where many water rights are pre-1922 Compact and considered to be protected from a Lower Basin call.

The threat of water shortage comes not only from the legal arena, but also from nature. Historically measured flows have found to be an unreliable indicator of future flows, which is doubly true now in the case of climate change. In an environment focused on divvying up water according to water right, it is natural that these managers would preference water rights data over other data when planning as water rights data is what is viewed to be valuable in the wider water community. This focus on water rights 
however may distract from the threat of changing water cycles which include earlier run off and longer drought periods. When taken in combination with the slow-to-change nature of bureaucracies, it may only take a severe shock to the system to adapt (Ludwig, Hilborn, \& Walters, 1993).

On the issue of conservation, efforts seem to be particularly constrained by water law as well as organizational goals and resources. The legal definition of beneficial use and the noble goal of water law to put all water to beneficial use also means that it is difficult to reduce water use without changes to regulations. This is particularly the case with lawn watering in residential areas, as watering the lawn is categorized under 'irrigation' and therefore a protected beneficial use. Water managers that work to promote conservation among water users have limited time and funding for projects. Typically, conservation efforts focus on infrastructure maintenance to reduce water loss within the organization through leaks or evaporation.

The surprising finding of this research is the use of water appropriation data in the use of planning water use. This challenges the historical assumption that data is the heart of natural resource management by bureaucracies. As past rulings constrain future decisions, lawyers have displaced knowledgeable locals and scientists as key information resources. In addition, the competitive nature of water rights turns the focus of management inward toward the organization's individual rights, possibly preventing coherent regional planning.

\subsection{Policy Implications}

Data use in water management is determined though the procedures formalized by organizations which have responded to the pressures of the regulatory environment (Abe et al., 1987; Clark, 1998). Research from this study also supports the claim that social norms influence how data is used in natural resource management. Among the water managers interviewed, all had basic knowledge of the bureaucratic procedures of water law, even though all had formal education in engineering or decades of experience working with municipal water systems. This information was most likely acquired 
through work experience, and interaction with peers. Thus, this research suggests that for data to be utilized differently in resource management increased communication with experts respected by managers combined with changes to bureaucratic procedures would facilitate change.

Findings from the literature review on the communication of knowledge between scientists and management suggest there is a divide among managers and scientists on priorities and understanding of scientific data (Jones, 2003; D. Michaels \& Monforton, 2005; Wynne, 1992). This divide stems from working in separate task environments and working toward separate organizational goals. I recommend to the scientific community to attend and participate in local meetings of water groups and basin roundtables. Gaining an understanding of the task environment of these hard working individuals would be the best method to adapting to communicate with their intended audience.

The limitations of time and money will always plague resource managers and scientists. In order to change the water consumption habits of residential water users, past research has shown that implementing water restrictions, land use codes, and building codes to be effective in reducing water use(Carter, Kreutzwiser, \& de Loë, 2005; Gleick \& MacDonald, 2010).

Education efforts are important, but should be considered as a way to support regulations aimed to reduce the culture of water consumption. Education, while an important tool for cultural change, can only do so much if people are not given the tools to implement what they learn, or if regulations are not there to support it. From my own experience working with a local watershed group I recognize that there are many organizations competing for the limited time and attention of the area's teaching staff. However, water managers may save themselves limited funds and time by partnering with local non-profits who already have working relationships in place with local schools to promote a water conservation ethic. For example the Shavano Conservation District works with local non-profits and schools to produce the $4^{\text {th }}$ Grade Natural Resource Festival attended by over 500 local schoolchildren annually. The Uncompahgre Watershed Partnership in Ouray County and the Western Slope Conservancy in Delta 
County hold annual river festivals to promote conservation. There is an opportunity for the GBRT or water managers to partner with these organizations to create a unified platform promoting water conservation. Within the task environment there is little water managers themselves can do to change the culture of water use within the larger community. However, there are a number of resources in the area water managers can work with to make an impact in residential water conservation.

In addition, reducing water consumption also reduces the funding for these organizations who are in the business of selling water. If authorities at the state or regional level wish to support conservation efforts these organizations need to be compensated for the loss of funding incurred from successful water conservation measures.

While regional planning is attempted through state mandated groups like the Gunnison Basin Round Table, the meetings are effectively closed to outside input. Representatives sit in an inward facing circle with visitors packed against a back wall. Meetings typically begin with an update on the activities of the Colorado Water Conservation Board by the board liaison. Monthly meetings are regularly attended by local non-profits and district representatives, however there is not a time open for public comments. Opening a set time during monthly meetings for public comment could work to open the planning process and information exchange to new possibilities and partnerships. This open time would also be the best opportunity for researchers to start a dialogue with water managers within water managers work environment. 


\subsection{Limitations}

Although the research expands our understanding of how the task environment constrains managers' focus to one type of data there are limitations to this case study to be recognized. While representatives from a municipality, water district, water users association, and federal agency were interviewed, particular towns within the Gunnison Basin were visited but not interviewed. This includes the City of Grand Junction, City of Delta and Paonia. While water managers for three municipalities were interviewed, managers from this area may have helped understand the culture of the valley areas, or alternative conservation efforts. These limitations have an impact on external validity and make it difficult to generalize to areas of large urban populations.

Based on the results of the study, there are several recommendations for future research. First, some of the limitations outlined in this study may be reduced if the research is replicated at places downstream and include interviews of additional water treatment workers. Water managers in the Gunnison Basin are shown to be working in a demanding task environment, do their coworkers in more insular positions experience the same level of behavior adaption to water law?

The results of this study clearly show that water law limits the types of data used in water management. What is less clear is if this translates to urban based basins or if this focus on data type negatively affects sustainable water management efforts. It is highly likely that water managers in highly competitive urban environments with more resources to acquire water utilize different tools to manage water resources. In an area like Denver or Colorado Springs which rely on post-1922 transmountain diversions, reliance on water law may not be the best tactic to achieve organizational goals. It is safe to assume that the requirements of managers working in an urban task environment would create a different outcome. These water managers may still rely heavily on bureaucratic rules and water law, but not on water allocation data for planning since the rights are not as secure under current water law.

Riparian law has changed over the last one hundred years but it is not nearly as visible or possibly as competitive as water management is in an arid region. However, 
water resources in the eastern U.S. are also under stress due to increasing population demands as well as climate change. It could be that prior appropriation's basic assumption of water as a limited resource and the need to assign beneficial uses, have advantages over a riparian based system. Or it could be found that the riparian based system creates its own set of data type biases that have an impact similar to the effect of water rights in prior appropriation. Furth research is needed to answer these questions.

Finally, this research supports the negative effect competition has on management of resources. The high level of competition creates a focus on the data type that will maintain organizational goals, not necessarily ensure future success. Further research in areas of water management with high levels of cooperation could further our understanding of the influence of the organizational task environment on natural resource management in creating sustainable management practices. 


\section{Conclusion}

The sustainable management of our natural resources is necessary to sustain communities through the world. This task which has historically relied on data will become more of a challenge in the future as what was once considered 'normal' for a region is altered through climate change. Understanding the environment water managers work in will be vital to developing future solutions to sustainability in a water scarce environment.

This research examines the role of data in management of a developed natural resource. By building a theory from information collected from a variety of sources, experiences, and formats, it found that data favored by water law is also favored by water managers. When managing developed natural resources shared by a variety of groups, governments and nations the institution which grows from the process will eventually determine the options available in managing the resource.

Findings from interviews indicate that there is not a consensus on the existence of climate change within the region. The effects of the phenomenon of dust on snow are acknowledged to hinder the effectiveness of water storage systems that operate on an annual cycle. Another, more eminent threat, to the region is disruption to water supplies through a curtailment put on the Upper Basin by the Lower Basin if the Lower Basin fails to meet its 1922 Compact delivery requirements. It is this legal threat brought about by twelve years of drought, which further focuses attention on an organizations water right year and amount allocated. This research also supports previous research on how organizational management will adhere to written procedure when engaging in a hostile and competitive resource environment.

There will probably never be a final resolution to the issue of water allocation, and what constitutes a beneficial use. Law has a history of changing at a slightly slower pace than more fluid social norms. However, understanding how water law influences the water mangers that manage local natural resources will be beneficial for future developments in how water is managed in water scarce regions. 


\section{Bibliography}

Abe, Takematsu, Pierce, John C., Loverich Jr., Nicholas P., \& Tsurutani, Taketsugu. (1987). Environmental Policy Elites' Trust of Information Sources. The American Behavioral Scientist, 30(6), 578-596.

Acheson, James M. (2006). Institutional Failure in Resource Management. Annual Review of Anthropology, 35, 117-134.

Bell, D. Craig. (1997). Water in the west today: a states' perspective. Western States Water Council Report to the Western Water Policy Review Advisory Commission. Springfield, VA.

Best, Allen. (2014). Bone on bone in the Colorado River: energy in times of drought, The Denver Post. Retrieved from http://www.denverpost.com/opinioncolumnists/ci_26300272

Bonds, Eric. (2011). The Knowledge-Shaping Process: Elite Mobilization and Environmental Policy. Critical Sociology, 37(4), 429-446. doi: 10.1177-0896920510379440

Bradeshaw, G. A. , \& Borchers, Jeffrey G. (2000). Uncertainty as Information: Narrowing the Science-Policy Gap. Conservation Ecology, 4(1).

Bureau of Reclamation. (2015). Upper Colorado River Basin. Western Colorado Area Office Tea-Cup Diagrams. Retrieved 2/23/2015, 2015, from http://www.usbr.gov/uc/wcao/water/basin/tc_cr.html

Bureau of Reclamation. (December 2007). Colorado River Interim Guidelines for Lower Basin Shortages and Coordinated Operations for Lake Powell and Lake Mead. Retrieved 3/7/2015, 2015, from http://www.usbr.gov/lc/region/programs/strategies.html

Bureau of Reclamation. (December 2012). Colorado River Basin Water Supply and Demand Study. Washington, D.C.: Goverment Printing Office.

Carter, Nicole, Kreutzwiser, Reid D., \& de Loë, Rob C. (2005). Closing the circle: linking land use planning and water management at the local level. Land Use Policy, 22, 115-127.

Cash, David, Clark, William, Alcock, Frank, Dickson, Nancy, Eckley, Noelle, \& Jäger, Jill. (November 2002). Salience, Credibility, Legitimacy and Boundaries: Linking Research, Assessment and Decision Making (John F. Kennedy School of Government, Trans.) Faculty Research Working Papers Series, (pp. 25). Cambridge, MA: Harvard University.

Cayan, Daniel R., Das, Tapash, Pierce, David W., Barnett, Tim P., Tyree, Mary, Gershunov, Alexander, \& MacDonald, Glen M. (2010). Future dryness in the southwest US and the hydrology of the early 21 st century drought. Proceedings of the National Academy of Sciences of the United States of America, 107(50), 21271-21276. doi: 10.2307/25756873

Charmaz, Kathy. (2006). Constructing Grounded Theory: A Practical GUide through Qualitative Analysis. Thousand Oaks, CA: Sage.

Chomko, Steven A., \& Crawford, Gary W. (1978). Plant Husbandry in Prehistoric Eastern North America: New Evidence for Its Development. American Antiquity, 43(3), 405-408.

Choo, Chun Wei. (1991). Towards an information model of organizations. The Canadian Journal of Information Science, 16(3), 32-62.

Clark, Roger N. (1998). Integrating Science and Policy in Natural Resource Management: lessons and opportunities from North America (F. Service, Trans.) Pacific Northwest Research Station General Technical Report. Seattle, WA: US Department of Agriculture.

Colorado River Water Users Association. (2014). Law of the River. Retrieved 2/22/2014, 2014, from http://www.crwua.org/colorado-river/uses/law-of-the-river

Corbin, Juliet, \& Strauss, Anselm. (1990). Grounded Theory Research: Procedures, Canons and Evaluative Criteria. Zeitschrift fur Soziologie, 19(Heft 6), 418-427.

Damanpour, Fariborz. (1991). Organizational Innovation: A Meta-Analysis of Effects of Determinants and Moderators. The Academy of Management Journal, 34(3), 555-590. doi: $10.2307 / 256406$ 
Davis, Sandra K. (2001). The politics of scarcity in the Western states. The Social Science Journal, $38,527-542$.

DiMaggio, Paul J., \& Powell, Walter W. (1983). The Iron Cage Revisited: institutional isomorphism and collective rationality in organizational fields. American Sociological Review, 48(2), 147-160.

Dravnieks Apple, Daina. (2001). Evolution of U.S. water policy: emphasis on the West (U. S. F. S. R. 5, Trans.) Forest Service Research Paper (pp. 20). Washington D.C.: United States Forest Service.

Edelman, Lauren B., \& Suchman, Mark C. (1997). The legal environments of organizations. Annual Review of Sociology, 23(1997), 479-515.

Flannery, Brenda L., \& May, Douglas R. (2000). Environmental Ethical Decision Making inthe U.S. Metal-Finishing Industry. The Academy of Management Journal, 43(4), 642-622.

Galbraith, Jay R. (1984). Organization Design: and information processing view. Army Organizational Effectiveness Journal(1), 21-26.

Gallaher, Samuel, Heikkila, Tanya, Patterson, Will, Frank, Vanessa, \& Weible, Christopher. (2013). Adapting water policy tools to new issues: lessons from Colorado's experience over time. Water Policy, 15, 43-60.

Getches, David H. (2001). The metamorphosis of western water policy: have federal laws and local decisions eclipsed the states' role? Stanford Environmental Law Journal, 20(3), 3-72.

Gober, Patricia, Kirkwood, Craig W., \& MacDonald, Glen M. (2010). Vulnerability assessment of climate-induced water shortage in Phoenix. Proceedings of the National Academy of Sciences of the United States of America, 107(50), 21295-21299. doi: 10.2307/25756877

Grantham, Joseph (Jody). (2011). Synopsis of Colorado Water Law. Colorado: Colorado State Engineer.

Greer, Linda, \& Steinzor, Rena. (2002). Bad Science. The Environmental Forum(January/February), 28-43.

Gregory, Doris H. (1991). The town that refused to die: Ridgway, Colorado 1890-1991. Ouray, Colorado: Cascade Publications.

Gunnison Basin Roundtable. (June 2014). Gunnison Basin Implimentation Plan - Draft. Montrose, CO: Gunnison Basin Round Table.

Hays, Samuel P. (1959). Conservation and the Gospel of Efficiency. Cambridge, MA: Harvard University Press.

Hobbs, Justice Gregory J. Hobbs, Jr. (1997). Colorado Water Law: an historical overview. Water Law Review, 1(1), 1-70.

Hobbs, Justice Gregory J. Hobbs, Jr. (2004). Citizen's Guide to Colordao Water Law (2nd ed.). Denver, CO: Colorado Foundation for Water Education.

Houck, Oliver. (2003). Tales from a Troubled Marriage: Science and the Law in Environmental Policy. Science, 302, 1926-1929. doi: 10.1126/science.1093758

Hundley, Norris Jr. (1975). Water and the West: the Colorado River Compact and the politics of water in the American West. Los Angeles: University of California Press.

Jerla, Carly. (2009). Colorado River Interim Guidelines for Lower Basin Shortages and the Coordinated Operations for Lake Powell and Lake Mead \& Efforts Addressing Climate Change and Variability. Intermountain West Climate Summary, 5, 5-7.

Johnson, Norman K., \& DuMars, Charles T. (1989). A survey of the evolution of western water law in response to changing economic and public interest demands. Natural Resources Journal, 29(Spring), 347-387.

Jones, Bryan D. (2003). Bounded Rationality and Political Science: Lessons from Public Administration and Public Policy. Journal of Public Administration Research and Theory, 13(4), 395-412. 
Kanzer, David. (November 17, 2013, November 7, 2014). Agricultural Conservation, Productivity and Water Transfers Workgroup. Paper presented at the Upper Colorado River Basin Water Conference, Grand Junction, CO.

Karkkainen, Bradley C. (2008). Getting to "Let's Talk": Legal and Natural Destabilizations and the Future of Regional Collaboration. Nevada Law Journal, 8(811), 811-829.

Kenny, Douglas, Bates, Sarah, Bensard, Anne, \& Berggren, John. (2001). The Colorado River and the inevitablility of instiutional change. Public Land \& Resources Law Review, 32(103), 103-152.

Kuhn, Eric. (2012). Risk management strategies for the Upper Colorado Basin (pp. 43). Glenwood Springs, Colorado: Colorado River Water Conservation District.

Kuhn, Eric. (2014, November 7, 2014). Colorado River Basin Water Supply and Demand Study. Paper presented at the 2013 Upper Colorado River Basin Water Conference, Grand Junction, CO.

Larson, Kelli L., Gustafson, Annie, \& Hirt, Paul. (2009). Insatiable thirst and finite supply: an assessment of municipal water conservation policy in Greater Phoenix, Arizona, 19802007. Journal of Policy History, 2.

Levin, Marc A. (1991). The information-seeking behavior of local government officials. American Review of Public Administration, 21(4), 271-286.

Ley, Aaron J. (2014). The Costs and Benefits of American Policy-Making Venues. Law \& Society Review, 48(1), 91-126.

Lindblom, Charles E. (1959). The science of "Muddling Through". Public Administration Review, 19(2), 79-88.

Lindquist, Evert A. (1988). What do decision models tell us about information use? Knowledge in Society, 1(2), 86-11.

Ludwig, Donald, Hilborn, Ray, \& Walters, Carl. (1993). Uncertainty, Resource Exploitation, and Conservation: Lessons from History. Science, 260(2 April), 35-36.

MacDonald, Glen M., \& Turner, B. L. (2010). Water, climate change, and sustainability in the southwest. Proceedings of the National Academy of Sciences of the United States of America, 107(50), 21256-21262. doi: 10.2307/25756871

Majchrzak, Ann. (1986). Information focus and data sources: When will they lead to use? Evaluation Review, 10(2), 193-215.

McDonald, Bill, \& Cech, Tom. (2012). Defend and Develop: Why the Colorado Water Conservation Board Was Created. In C. W. C. Board (Ed.). Denver Colorado: Colorado Water Conservation Board.

Meko, David M., Woodhouse, Connie A., Baisan, Christopher A., Knight, Troy, Lukas, Jeffrey, Hughes, Malcom K., \& Salzer, Matthew W. (2007). Medieval drought in the upper Colorado Rier Basin. Geophysical Research Letters, 34(10).

Merchant, Carolyn. (2002). The Columbia Guide to American Environmental History. New York: Columbia University Press.

Merton, Robert. (1950). Bureaucratic Structure and Personality. Social Forces, 18(4), 560-568.

Michaels, David, \& Monforton, Celeste. (2005). Scientific Evidence in the Regulatory System: Manufacturing Uncertainty and the Demise of the Formal Regulatory System. Journal of Law and Policy, 13(1), 17-41.

Michaels, Sarah. (2009). Matching knowledge brokering strategies to environmental policy problems and settings. Environmental Science \& Policy, 12(7), 994-1011. doi: 10.1016/j.envsci.2009.05.002

Miller, Kathleen A., \& Rhodes, Steven, L. (1997). Water Allocation in a Changing Climate: Institutions and Adaptations. Climate Change, 35, 155-177.

Mimiaga, Jim. (2014). Powell could 'call' on reservoirs: Low reservoir threatens hydroelectric plant, The Dolores Star. Retrieved from http://www.cortezjournal.com/article/20140514/DS03/140519903/-1/News 
Mooney, Chris. (2004). Paralysis by Analysis. The Environmental Forum, September/October, 38-42.

Mulroy, Patricia. (2008). Collaboration and the Colorado River Compact. Nevada Law Journal, 8(Spring), 890-895.

Nabhan, Gary Paul. (1988). Invisible Erosion: The Rise and Fall of Native Farming. Journal of the Southwest, 30(4), 552-572.

O'Reilly, Charles A. III. (1982). Variations in decision markers' use of information sources: the impact of quality and accessibility of infomration. Academy of Management, 25(4), 756-771.

O'Reilly, Charles A. III. (1983). The use of information in organizational decision making: a model and some propositions. Research in Organizational Behavior, 5, 103-139.

Ostrom, Elinor, Burger, Joanna, Field, Christopher B., Norgaard, Richard B., \& Policansky, David. (1999). Revisiting the Commons: local lessons, global challenges. Science, $284(9$ April ), 278-282. doi: 10.1126/science.284.5412.278

Painter, Thomas, Deems, Jeffery S., Belnap, Jayne, Hamlet, Alan F., Landry, Christopher C., \& Udall, Bradley. (2010). Response of Colorado River runoff to dust radiative forcing in snow. Proceedings of the National Academy of Sciences of the United States of America, 107(40), $17125-17130$.

Pettit, Jan. (2012). Utes: the mountain people (Third ed.). Boulder, CO: Johnson Books.

Phillips Whitmore, Martha. (2013). Water Law for the Non-Lanyer (presentation handout). Ouray, CO. Pinchot, Gifford. (1910). The Fight for Conservation. New York: Doubleday, Page \& Company.

Pitelis, Christos N. (2007). A Behavioral Resource-Based View of the Firm: The Synergy of Cyert and March (1963) and Penrose (1959). Organization Science, 18(3), 478-490. doi: $10.2307 / 25146113$

Powell Consortium. (1995). Sever Sustained Drought: Managing the Colorado River System in Times of Water Shortage. In P. Consortium (Ed.), (Vol. 1). Tucson, AZ: Arizona Water Resources Research Center.

Pratt, April. (2010). A case study of the Uncompahgre Valley Water Users' Association's Management of its water commons (C. W. Institute, Trans.) Federal Bureaucracy and Locality. Fort Collins, CO: Colorado State University.

Project 7. (2014). Project 7 Water Authority. Retrieved October, 2014, 2014, from http://www.project7water.org/

Rajagopalan, Balaji, Nowak, Kenneth, Prairie, James, Hoerling, Martin, Harding, Benjamin, Barsugli, Joseph, . . . Udall, Bradley. (2009). Water supply risk on the Colorado River: can management mitigate? Water Resources Research, 45. doi: 10.1029/2008WR007652

Reisner, Marc. (1986). Cadillac Desert.

Rice, Leonard, \& White, Michael D. (1987). Engineering aspects of water law. New York: John Wiley $\&$ Sons.

Sabo, John L., Sinha, Tushar, \& et al. (2010). Reclaiming freshwater sustainability in the Cadillac Desert. Proceedings of the National Academy of Sciences of the United States of America, 107(50), 21263-21270. doi: 10.2307/25756872

Schlager, Edella, Heikkila, Tanya, \& Case, Carl. (2012). The costs of compliance with interstate agreements: lessons from water compacts in the Western United States. Publius: The Journal of Federalism, 42(3), 494-515. doi: 10.1093/publius/pjs017

Schneider, Mark A. (2006). The Theory Primer: A Sociological Guide. Lanham, MD: Rowman \& Littlefield Publishers, Inc.

Scott, W. Richard. (2003). Organizations: rational, natural, and open systems (Fifth ed.). Upper Saddle River, New Jersey: Prentice Hall.

Shupe, Steven J., Weatherford, Gary D., \& Checchio, Elizabeth. (1989). Western water rights: the era of reallocation. Natural Resources Journal, 29(Spring), 414-434.

Sibley, George. (2012). Water Wranglers: The 75 Year History of the Colorado River District. Glenwood Springs, CO: Colorado River District. 
Sibley, George. (2013). The Gunnison River Basin: A Handbook for Inhabitants. In Public Education \& Outreach Committee of the Gunnison Basin Roundtable \& Water Center at Colorado Mesa University (Ed.). Grand Junction, CO.

Simon, Herbert. (1978). Rationality as process and thought. The American Economic Review, 68(2), $1-16$.

Simon, Herbert. (1996). The Sciences of the Artificial (Third ed.). Cambridge, MA: The MIT Press.

Smith, P. David. (2000). Mountains of Silver: the story of Colorado's Red Mountain mining district. Ouray, CO: Western Reflections.

Smith, P. David. (2003). A quick history of Ouray. Montrose, CO: Western Reflections, Inc.

Staff. (2014, February 8, 2013). State-Imposed water efficiency measures trickle toward Ouray residents, The $W$ atch Retrieved from http://www.thewatchmedia.com/ouray-briefsstate-imposed-water-efficiency-measures-trickle-toward-ouray-residents-2/

Strauss, Anselm, \& Corbin, Juliet. (1994). Grounded theory methodology. In N. K. Denzin \& Y. S. Lincoln (Eds.), Handbook of qualitative research (pp. 273-285). Thousand Oaks, CA: Sage.

Udall, Bradley. (2014). Colorado River: Myths and Realities [Webinar]. Tucson, AZ: Southwest Climate Science Center.

Udall, Bradley. (February 27, 2014). Colorado River: Myths and Realities Southwest Climate Science Center Webinar: Getches-Wilkinson Center

Udovyk, Oksana, \& Gilek, Michael. (2013). Coping with Uncertainties in Science-Based Advice Informing Environmental Management of the Baltic Sea. Environmental Science \& Policy, 29, 12-23. doi: 10.1016/j.envsci.2013.01.015

Vig, Norman J., \& Kraft, Michael E. (Eds.). (2010). Environmental Policy: new directions for the twentyfirst century (7th ed.). Washington D.C.: CQ Press.

Wasim, I Al-Habil. (2011). Rationality and Irrationality of Max Weber's Bureaucracies. International Journal of Management \& Business Studies, 1(4), 106-165.

Waterman, Johnathan. (2010). Running Dry: a journey from source to sea down the Colorado River. Washington, D.C.: National Geographic.

Weber, Max. (1968). Economy and Society (G. Roch \& C. Wittich, Trans. G. Roth \& C. Wittich Eds.). Los Angeles: University of California Press.

Weber, Max. (1969). Law and Social Structure. In V. Aubert (Ed.), Sociology of Law (pp. 153-160). Baltimore, MD: Penguin Education.

Wellstead, Adam. (2011). Climate change policy capacity at the sub-national government level. Journal of Comparative Policy Analysis: Research and Practice, 13(5), 461-478. doi: 10.1080/13876988.2011.605937

Wilke, Philip J., Whitaker, Thomas W., \& Hattori, Eugene. (1977). Prehistoric squash (Curcurbita pepo L.) from the Salton Basin. Journal of California Anthropology, 4(1), 55-59.

Wilkinson, Charles F. (1992). Crossing the next meridian: land, water, and the future of the West. Washington, D.C.: Island Press.

Winchester, John N. (2001). A historical view: transmountain diversion development in colorado. Denver, CO: United States Committee on Irrigation and Drainage.

Wolfe, Sarah, \& Brooks, David B. (2003). Water scarcity: An alternative view and its implications for policy and capacity building. Natural Resources Forum, 27, 99-107.

Woodhouse, Connie A., Meko, David M., MacDonald, Glen M., Stahle, Dave W., Cook, Edward R., \& Turner, B. L. (2010). A 1,200-year perspective of 21 st century drought in southwestern North America. Proceedings of the National Academy of Sciences of the United States of America, 107(50), 21283-21288. doi: 10.2307/25756875

Wynne, Brian. (1992). Uncertainty and Environmental Learning: Reconceiving Science and Policy in the Preventive Paradigm. Global Environmental Change(June), 111-127. 


\title{
Appendix A - Interview Questions
}

\author{
City / Town Planners, Water District Personnel
}

1. How much of your time involves planning for future water use?

2. How are decisions made regarding water storage and allocation?

3. Do you read or follow reports (like the Colorado River Basin Report from the Bureau of Reclamation) on water use as they come out?

a. Are there any sources or groups you like to follow for water use information?

b. Are you a member of any water professional groups?

c. Are there sources of data you find more reliable than others?

i. Why?

4. Do you track water use here?

5. Do you think there is enough water in the Gunnison Basin to meet local needs? Why or why not?

6. How do you plan for future water use?

a. Has the planning process changed since you started working here?

b. How?

7. How is climate change or projected water shortages taken into account when planning for future water use?

8. Are there contingency plans to supply water during drought?

a. If so, what do these plans entail?

9. Have you had to implement drought contingencies in the past five years?

a. If yes, how effective do you think the policy was to conserve water?

10. What do you think are the threats to the town/districts ability to supply water in the next 20 to 40 years?

11. How do you feel about the population growth going on in Ouray County?

a. Do you think this is affecting water access?

12. How old are your employer's water rights?

a. How often in the past ten years has your water been "called" by a senior water rights holder?

13. Is there anything else you think I should know? 


\section{Appendix B - Text of Informed Consent Data and Water Policy in Ouray County Colorado: A Case}

\section{Study}

You are being asked to participate in a research study conducted by Rhianna Williams and Richelle Winkler from the Social Sciences Department at Michigan Technological University. Your participation in this study is entirely voluntary. Please read the information below and ask questions about anything you do not understand, before deciding whether or not to participate.

\section{Purpose}

This research proposes to use interviews, reviews of historical documents and content analysis to explore how data informs water policy. Records of historic to current compacts, laws, and agreements will be reviewed through content analysis to understand how data has informed previous policy. Local government and public works employees will be interviewed to understand how local data is collected, how the data is used to create and execute policy, what policies exist to mitigate drought and water calls, and how public officials plan for future water use.

\section{Procedures}

If you choose to participate in this study, you are asked to spend about one hour talking with a researcher about water use, water policy, and opinions about how water should be managed in the future. With your permission, the interview will be audiorecorded.

Following the interview, the researcher will transcribe the recording. This interview transcript will be shared among the researcher and an academic committee made up of three faculty members at Michigan Technological University, although names will be kept confidential. All recordings will be destroyed after transcription. Transcribed interviews will be kept for three years, without any identifying information. 


\section{$\underline{\text { Risk }}$}

This project is not intended to cause any physical or emotional discomfort. However, you may choose to share sensitive and confidential information during the interview. All efforts will be made to ensure confidentiality. In the event of physical and/or mental injury resulting from participation in this research project, Michigan Technological University does not provide any medical, hospitalization or other insurance for participants in this research study, nor will Michigan Technological University provide any medical treatment or compensation for any injury sustained as a result of participation in this research study, except as required by law.

\section{$\underline{\text { Potential Benefits to You }}$}

This study will not bring you specific benefits outside of an opportunity to share your views and opinions. Your participation, however, will be beneficial in informing how future policy may be implemented, and informing the larger scientific community of water policy and use at the local level. At your request we will send you a copy of the published thesis by email.

\section{Privacy and Confidentiality}

Any information that is obtained in connection with this study and that can be identified with you will remain confidential and will be disclosed only with your permission or as required by law.

\section{Participation and Withdrawal}

You can choose whether or not to be in this study. If you volunteer to be in this study, you may withdraw at any time without consequences of any kind. You may also refuse to answer any questions you do not want to answer.

\section{$\underline{\text { Research Study Results }}$}

If you wish to learn about the results of this research study, or have questions about this study contact Rhianna Williams, 970-325-3010 or at rlwillia@mtu.edu. 


\section{$\underline{\text { Rights of Research Subjects }}$}

The Michigan Tech Institutional Review Board has reviewed my request to conduct this project if you have any concerns about your rights in this study, please contact the Office of Compliance, Integrity, and Safety at 906-784-2902 or email IRB@mtu.edu.

\section{Agreement to Participate}

By signing this consent form below, you are stating the following:

- The details of this research study have been explained to me including what I am being asked to do and the anticipated risks and benefits;

- I have had an opportunity to have my questions answered;

- I am voluntarily agreeing to participate in the research as described on this form;

- I have been given a copy of this document for my records;

- I may ask more questions or stop participating at any time without penalty.

\section{Print Name:}

Signature:

\section{Date:}




\section{Appendix C - Data Dictionary}

\section{Adapt to the Desert}

The belief that people are not living within their water means given by the environment. The idea that having a lawn of water sucking plants is inappropriate for the area. People must adapt to the environment they are living in.

\section{Administration Duties}

more of the desk jockey items the water manager has to attend to. Regular filing of reports, meetings attended, agreements written etc. Not directly tied to physically managing water.

\section{Ag to Municipal Conversion}

Almost all rights in the valley were originally appropriated to and perfected by farmers. In such cases there is usually a system of small canals in place. Ag to Municipal conversion is then the conversion of a water right from agricultural beneficial use to municipal beneficial use.

\section{Beneficial Use}

"Beneficial use is the legal basis for allowing all diversions of water from surface and groundwater supplies. Water that is removed from the state's rivers, streams and underground must serve a beneficial purpose to mankind, either economically, socially, recreationally, hygienically or other ways, or it is not granted a right. To allow water resources to benefit the greatest number of people, use of water must be reasonably efficient. A water right is a right to use the amount of water necessary to accomplish beneficial use without waste." From Colorado River District, Water Glossary (8/1/14) www.crwcd.org/page_100 


\section{Climate vs. Hydrology}

Climate change is affecting the American Southwest through more severe droughts and floods. However, climate change is not accepted by all people managing water in the SW. Instead of accepting climate change, they prefer to say the current drought is part of the natural hydrological cycle.

\section{Colorado River Compact}

"Water allocation problems along the full length of the Colorado River prompted the 1922 Colorado River Compact between Colorado, Wyoming, Utah, New Mexico, Nevada, Arizona and California. The Colorado River was split into Upper Basin and Lower Basin segments, with Lee's Ferry in Arizona serving as the dividing point and it was agreed to apportion the waters of the Colorado River to these two basins. Each basin would than allocate water among its states. In 1948, the Upper Basin states of Colorado, Wyoming, Utah and New Mexico agreed on apportioning the Upper Basin's share."

www.crwcd.org/page_100

\section{Community Capitals}

Cornelia and Jan Flora (2008) developed the Community Capitals Framework as an approach to analyze how communities work. Based on their research to uncover characteristics of entrepreneurial and sustainable communities, they found that the communities most successful in supporting healthy sustainable community and economic development paid attention to all seven types of capital: natural, cultural, human, social, political, financial and built. In addition to identifying the capitals and the role each plays in community economic development, this approach also focuses on the interaction among these seven capitals as well as how investments in one capital can build assets in others. http://www.soc.iastate.edu/staff/cflora/ncrcrd/capitals.html 


\section{Built Capital}

The infrastructure that supports the community, such as telecommunications, industrial parks, main streets, water and sewer systems, roads, etc. Built capital is often a focus of community development efforts. Here we are looking at the canals, laterals, tunnels, pipelines, reservoirs, hydro plants that are built to support and take advantage of the water system.

\section{Cultural Capital}

Reflects the way people "know the world" and how to act within it. Cultural capital includes the dynamics of who we know and feel comfortable with, what heritages are valued, collaboration across races, ethnicities, and generations, etc. Cultural capital influences what voices are heard and listened to, which voices have influence in what areas, and how creativity, innovation, and influence emerge and are nurtured. Cultural capital might include ethnic festivals, multilingual populations or a strong work ethic.

\section{Financial Capital}

The financial resources available to invest in community capacity building, to underwrite businesses development, to support civic and social entrepreneurship, and to accumulate wealth for future community development.

\section{Human Capital}

The skills and abilities of people, as well as the ability to access outside resources and bodies of knowledge in order to increase understanding and to identify promising practices. Human capital also addresses leadership's ability to "lead across differences," to focus on assets, to be inclusive and participatory, and to be proactive in shaping the future of the community or group. 


\section{Natural Capital}

Assets that abide in a location, including resources, amenities and natural beauty. For this study, we would be talking about water flow, snowmelt, natural lakes, forest cover, etc.

\section{Political Capital}

The ability to influence standards, rules, regulations and their enforcement. It reflects access to power and power brokers, such as access to a local office of a member of Congress, access to local, county, state, or tribal government officials, or leverage with a regional company.

\section{Social Capital}

Reflects the connections among people and organizations or the social glue to make things happen. Bonding social capital refers to those close ties that build community cohesion. Bridging Social Capital involves weak ties that create and maintain bridges among organizations and communities.

\section{Conservation}

Conservation is the efforts to reduce overall water consumption and loss throughout a water system. Examples of conservation through water consumption reduction include: changing agricultural irrigation practices, low flow fixtures in municipal areas, restriction of lawn irrigation or xeriscaping lawns.

Examples of conservation of reduction of water loss include: lining of canals to reduce leaks, covering ponds to reduce evaporation, etc.

\section{Data for Protection of Water Resources}

Data collected to ensure the users continued right to use water. This can be data collected to prove the water is being used, the documentation needed to maintain a water right in court. 


\section{Data for Water Management}

Data that is used to run the built portions of the water system. Data used to run canals, reservoirs, hydropower and dams.

\section{Decision Making}

A trigger for decision making, for example "when the flows are between this and that, then I do A or B"

\section{Interconnectedness}

This is entities working with one another to manage water resources. So the seven entities that got together to run Project 7, or other examples of people and entities working through cooperative means rather than adversarial means (lawsuits, etc) to achieve water management goals. Any form of cooperation.

\section{Knowledge from Experience}

Knowledge gained from being on the job, from experience.

\section{Knowledge from School}

Knowledge gained by going to an accredited program like an undergraduate or graduate degree, or a professional workshop.

\section{Knowledge from Social}

Knowledge gained from social connections, talking to people outside of work. Knowledge gained from a social network or personal connections.

\section{Membership}

Does the subject belong to a profession water group? 


\section{Planning Water Use}

The ways people plan for (or don't plan for) future water use.

\section{Potable Water}

All water that comes out of the water treatment plant and supplied to homes, municipalities and industry.

\section{Prior Appropriation}

"Prior appropriation is the basis for Colorado's water laws and its priority system of allocating water. The prior appropriator, or the first person to put water to a beneficial use, has the superior right to use water in instances when there is not enough water to meet the needs of all water users. Water users who put water to beneficial use after others must subordinate their use to those who previously established a water use. “

www.crwcd.org/page_100

\section{Qualitative Data}

Data gleaned from word of mouth, personal experience

\section{Quantitative Data}

Data of number gleaned from equipment or experimentation. Examples are USGS flow meters

\section{Raw Water}

All water before reaching the water treatment plant. Runoff, snowmelt, river and reservoir water. Ditch water and ag water is Raw Water.

\section{Using or Gathering Data}

Looking for anything related to data gathering or using of data for management purposes. What reports they read, mention of flow or snowpack. 


\section{'Use it or Lose it'}

There is a belief in the west that water that isn't used for a beneficial use is wasted. So, in order to prevent people from hording water rights, rights holders must prove that they are using their full water right every ten years in water court or risk losing some or all of their water right.

Also, in discussions within Colorado and throughout the Colorado River Basin, people work to protect they water they have by proving they need all the water they have available. For example, in Ouray County, the county attorney said "We need to show the Front Range we are using all of our water. That there is no water here for them to take."

\section{Validity of Data}

What data is seen as unbiased, reasonable or justifiable. What data is seen as unreliable or faulty.

\section{Water 'Call'}

When a person makes a 'Call' on the river. It is a written request stating they are not getting their full allotment. Water Calls are managed by the water court's local district and usually involves cutting off the supply of junior rights holders.

\section{Water law}

Anything to do with regulations, law, or legal precedents dealing with water. 


\section{Water Right}

"A water right is a private property right in the State of Colorado that establishes in what priority a water user may use water for a beneficial purpose. The priority in which someone can divert water to put it to a beneficial use is granted by the water courts in the State of Colorado. A water right allows diversion of a certain amount of water, in a specified order among other water users, from a certain point along a body of water and for a specified purpose. The older, or more senior, the water right, the fewer other water users whose needs must be satisfied before the user is allowed to divert water. The younger, or more junior, the water right, the greater number of senior water rights that must be satisfied before a junior right can divert water." www.crwcd.org/page_100

\section{Where the Water is vs Where the People Are}

There is a saying for Colorado that " $80 \%$ of the People a on the Front Range while $80 \%$ of the Water is on the Western Slope" and another for the Colorado River Basin " $80 \%$ of the People are in the Lower Basin while $80 \%$ of the Water is in the Upper Basin." This is the basis of the arguments for moving water from where it is to more populated areas. Imbedded in this statement is also the argument that the water needs to go where there is more people, that that would be the right thing to do because it would be put to better use. 


\section{Appendix D - Copyright Permission}

The following figures are from publications prepared by an office or employee of the United States Government as part of their official duties and not subject to copyright in the United States per United States Code Title 17 Section 105.

Figure 1: U.S. Bureau of Reclamation. (Dec. 2012). Supply and Demand Gap Chart from Colorado River Basin Water Supply and Demand Study. U.S. Department of the Interior, Government Printing Office: Washington, D.C.

Figure 2: Colorado River Basin, U.S. Bureau of Reclamation. (Dec. 2010). Colorado River Basin Water Supply and Demand Study. U.S. Department of the Interior, Government Printing Office: Washington, D.C.

Figure 4: U.S. Bureau of Reclamation. (February 22, 2015). Teacup diagram showing reservoir levels in the Gunnison Basin. Retrieved 2/22/2015 from: http://www.usbr.gov/uc/water/basin/tc_gr.html. Diagram automatically generated using current data provided by the U.S. BOR on the U.S. BOR website. 